\title{
PLANT EXPLOITATION BY THE INHABITANTS OF THE WIELBARK CULTURE SETTLEMENT COMPLEX NEAR THE VILLAGE ULÓW, SE POLAND, AT THE BACKGROUND OF THE NATURAL ENVIRONMENT
}

\author{
Irena Agnieszka PideK ${ }^{1}$, Krystyna Wasylikowa ${ }^{2}$, \\ Magdalena Moskal-Del Hoyo ${ }^{2}$
}

A u thors' address e s: 1 - Faculty of Earth Sciences and Spatial Management, Maria Curie-Skłodowska University, al. Kraśnicka 2d, 20-718 Lublin, e-mail: i.pidek@poczta.umcs.lublin.pl; 2 - W. Szafer Institute of Botany, Polish Academy of Sciences, Lubicz 46, 31-512 Kraków, e-mail: k.wasylikowa@botany.pl,m.moskal@botany.pl

A b s t r a c t. Palynological and archaeobotanical investigations were carried out on a large settlement complex of the Wielbark culture dated to the late Roman and early Migration periods, situated near the village Ulów in the Middle Roztocze, SE Poland. Pollen diagrams which covered the Subboreal and Subatlantic periods revealed the development of forests with European hornbeam Carpinus betulus, lime Tilia sp., oak Quercus sp. and common beech Fagus sylvatica in the Subboreal and the spread of silver fir Abies alba in the Subatlantic phase. Pollen spectra from both periods provided the evidence of cereal cultivation and animal grazing in the neighbourhood of the settlement. The analysis of daub coming from the Wielbark culture features documented the predominance of common barley Hordeum vulgare and common millet Panicum miliaceum among the cereals and probably lesser significance of wheat, emmer Triticum dicoccon or einkorn T. monococcum. Charcoal assemblages were examined from the settlement and from the cemetery. Taking into account the number of charcoal fragments, Quercus sp. was the most abundant taxon, followed by Fagus sylvatica, Carpinus betulus, Scots pine Pinus sylvestris, and birch Betula sp. Other taxa were only occasionally found. The taxonomic lists were very similar in the settlement and the cemetery, but there was a discrepancy between the predominating taxa since birch was the most frequent at the cemetery and oak in the settlement.

K e y w o r d s: pollen analysis, fruits, seeds, wood charcoals, Wielbark culture, Roman Period, Poland

\section{INTRODUCTION}

Palynological and archaeobotanical studies presented in this article were undertaken in connection with archaeological investigations carried out in the Middle Roztocze, SE Poland, in the vicinity of the village Ulów, Tomaszów Lubelski commune, Lublin province (Fig. 1). The Roztocze ridge is a NW-SE elongated range of hills extending from 


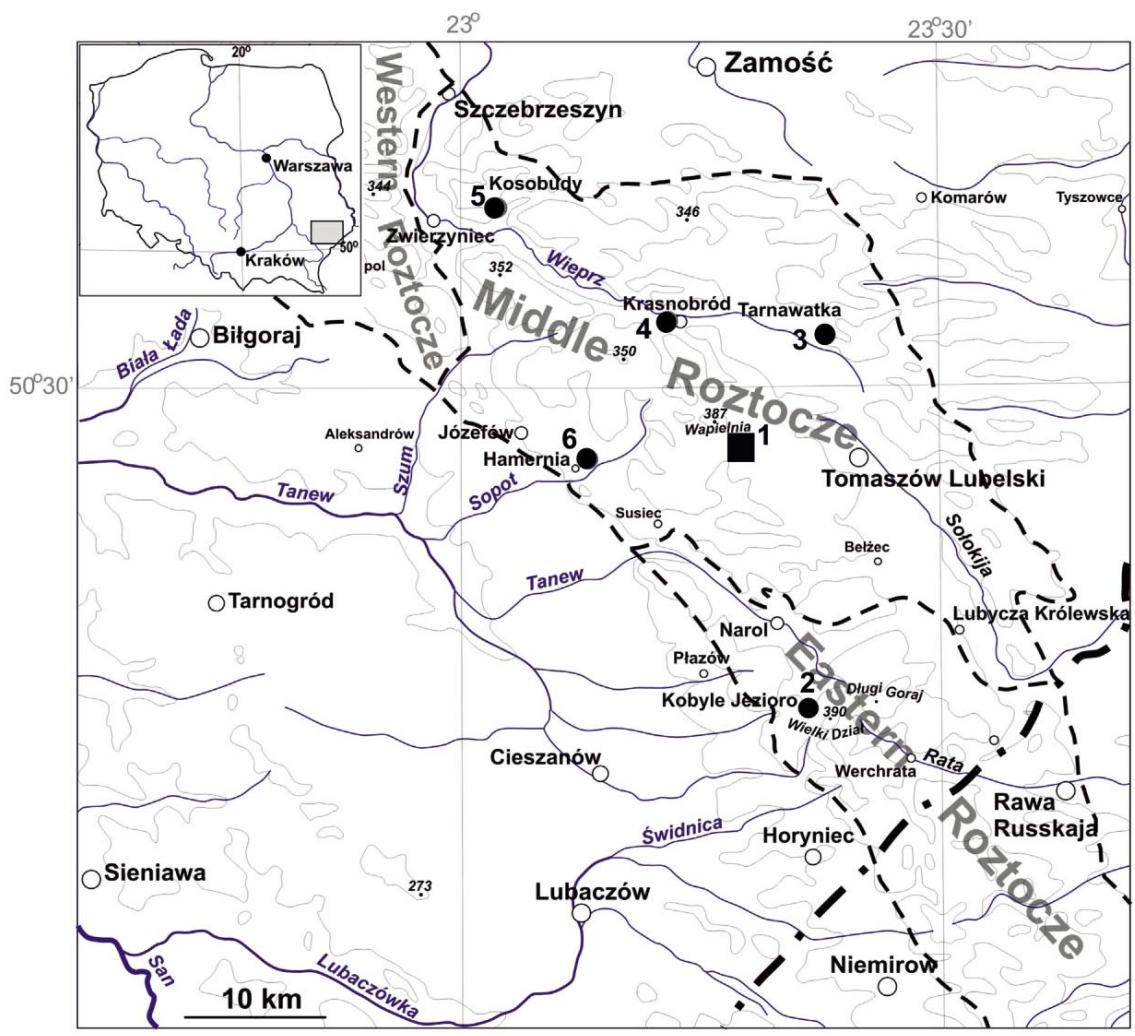

Fig. 1. The location of Ulów settlement area (1) in relation to the sites studied by pollen analysis (2-6) in the Roztocze Upland (from KorzeŃ et al. 2015, slightly changed)

the Lublin upland to the western Ukraine. The culminations of the Middle Roztocze are up to $350 \mathrm{~m}$ a.s.l. high, with the highest elevation Wapielnia $385 \mathrm{~m}$ a.s.l. located near the Ulów village. Hills are covered with forests which in about $60 \%$ have more or less natural character. Nowadays 19 different forest associations are distinguished of which the most precious are fir tree woods (Abietetum polonicum) covering lower and middle parts of hill slopes and Carpathian beech forests (Dentario glandulosae - Fagetum) growing on their summits (IZDEBSKI et al. 1992; IZDEBSKI 2002). Both forest types are characteristic for the lower subalpine forests of the Carpathian Mountains. In the river and stream valleys there occur alder carrs and alder swamps. They are usually surrounded by a narrow belt of wet oak-spruce woods. Different pine forests occur on plains and dunes (IZDEBSKI et al. 1992; IZDEBSKI 2002). Meadow communities form the greatest complexes in the Wieprz river valley. Roztocze range represents a significant climatic border between the Atlantic climate influences from the west and continental ones from the east. In the Roztocze several tree species, first of all beech and fir, but also sycamore, spruce and latifolious lime, reach the north-eastern limit of their continuous extent (IzDEBSKI et al. 1992). The regional climate of the Roztocze is particularly favourable for trees demanding suitable moisture of air and soil, i.e. Fagus sylvatica and Abies alba. 
Archaeological excavations carried out since 2001 in the vicinity of the village Ulów under the supervision of Dr. Barbara Niezabitowska-Wiśniewska $(2008,2017)$ resulted in the discovery of a large settlement complex dated to the late Roman and early Migration Periods as well as some traces of cultures dated to the Palaeolithic, Mesolithic, Neolithic, Bronze Age and early Middle Ages (NieZABITOWsKA-WiśNiEWsKA 2008; NieZABITOWSKA-WiśNIEWSKA, WiŚNIEWSKI 2011). In order to reconstruct the vegetation of settlement periods, agricultural activities and timber exploitation by the ancient population from the initiative of Dr. Niezabitowska-Wiśniewska palynological investigations (I.A. Pidek), studies of fruits/seeds (K. Wasylikowa) and of wood charcoal (M. Moskal-del Hoyo) were undertaken.

\section{MATERIAL AND METHODS}

For pollen analysis 4 cores designated as sites $68 \mathrm{a}, 68 \mathrm{~b}, 71$ and 118 were collected from two small peaty valleys (Fig. 2) discovered during geomorphological investigations carried out in the surroundings of the Ulów settlement complex (RoDzIK, NITYCHORUK 2017). The coring was performed with the use of the Instorf-type sampler (Figs 3, 4).

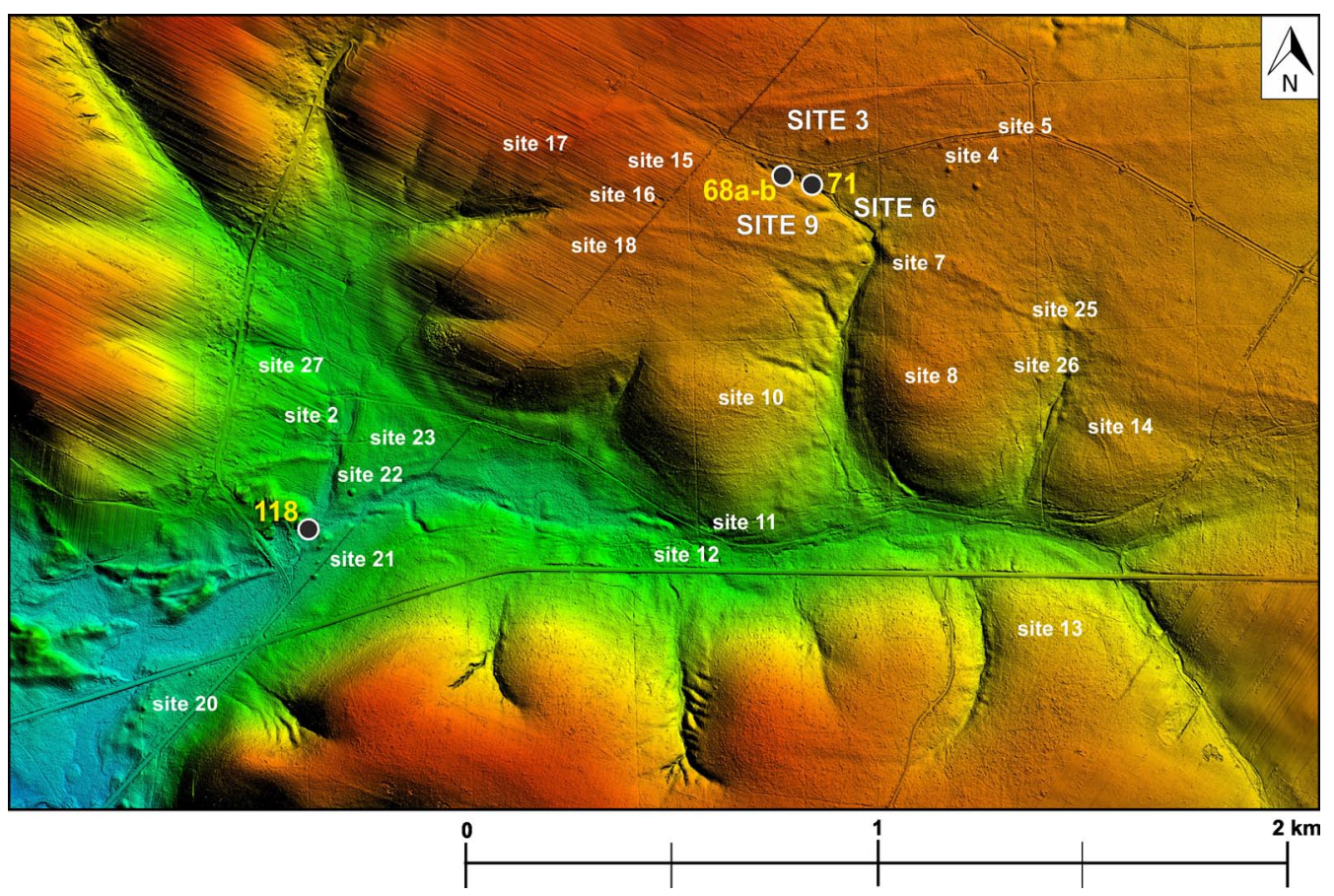

Fig. 2. The distribution of archaeological sites in Ulów area (site 3-27) and the position of pollen profiles 68a, 68b, 71 and 118, against the background of the map after NiEZABITOWSKA-WiŚNIEWSKA (2017) this volume, Fig. 3 


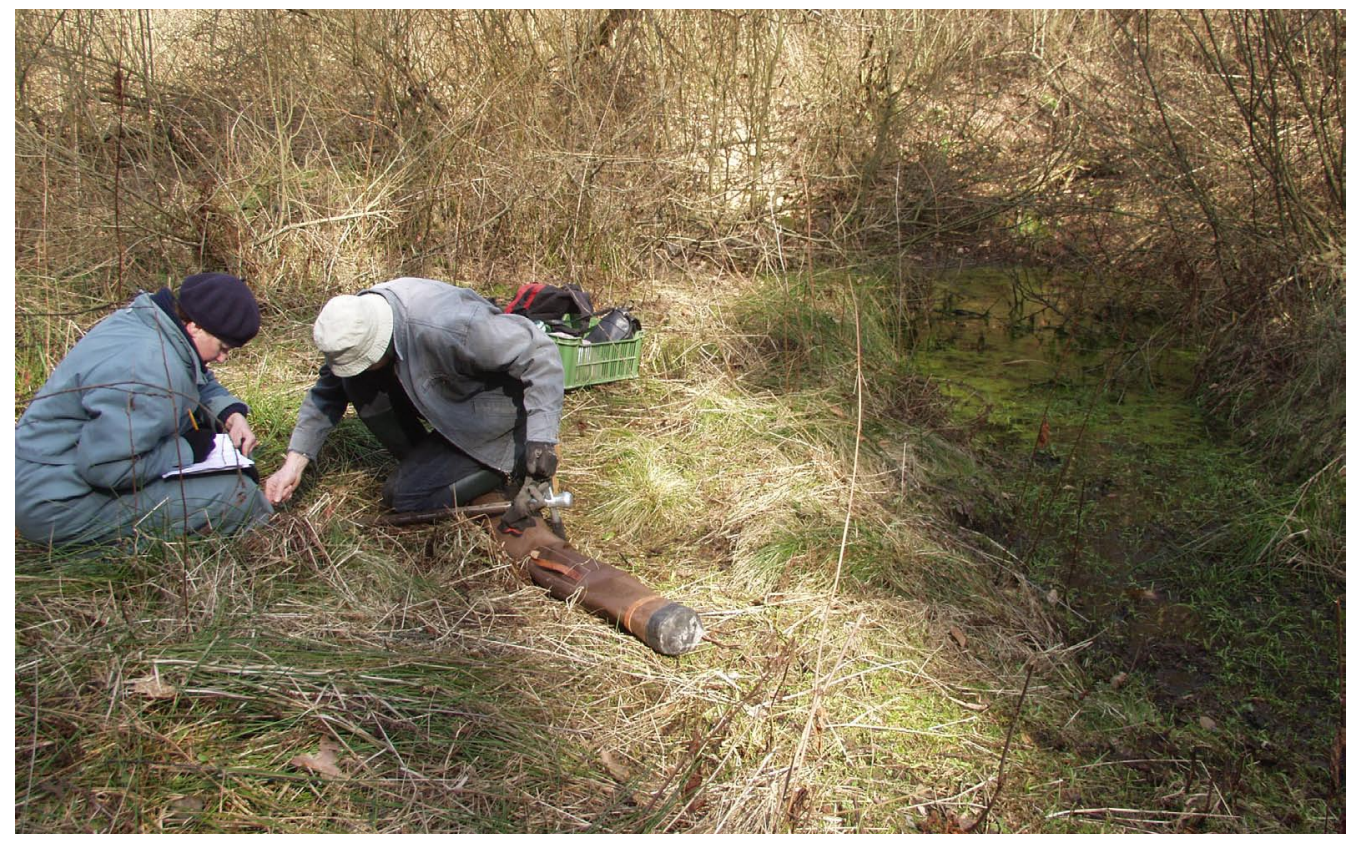

Fig. 3. View of the coring sites $71,68 \mathrm{a}$ and $68 \mathrm{~b}$. Phot. P. Mroczek

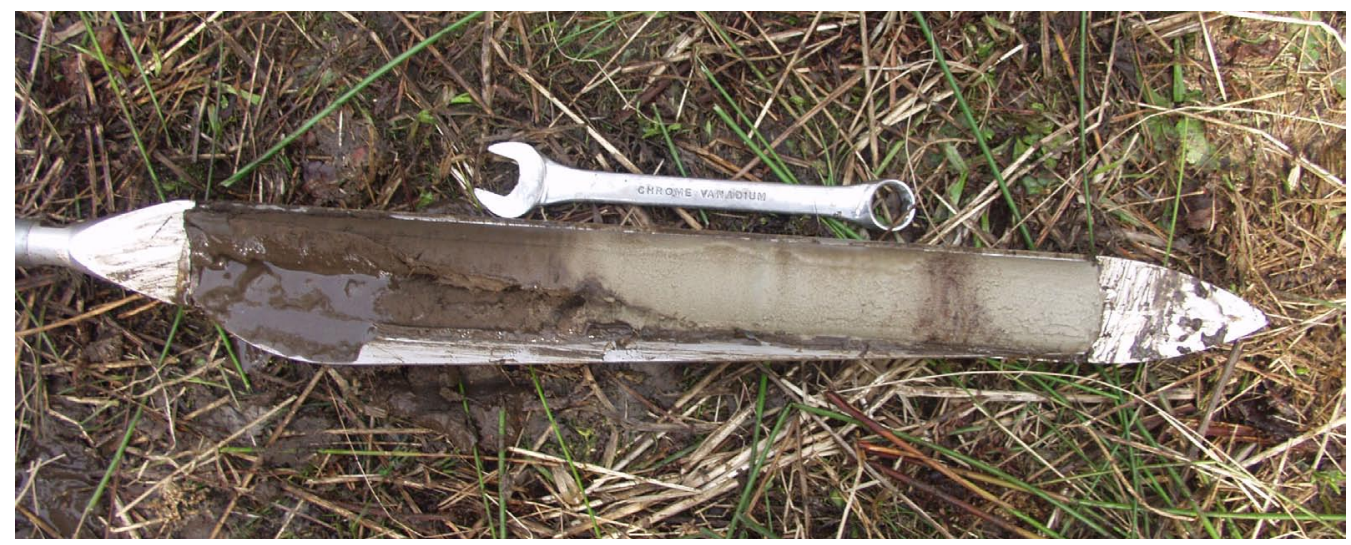

Fig. 4. Core fragment. Phot. P. Mroczek

\section{Sediment description}

Profile $68 \mathrm{a}$, bottom of a small valley in its upper part

0-4 cm - Sphagnum moss and litter

4-11 cm - very well decomposed peat, silty

$11-42 \mathrm{~cm}$ - well decomposed sedge-moss peat

$42-100 \mathrm{~cm}$ - sand with bands of organic matter at the top 
Profile $68 \mathrm{~b}$, bottom of a small valley in its upper part

0-30 cm - well decomposed peat with black mud, silty

30-45 cm - well decomposed sedge-moss peat, wood at the bottom

$45-87 \mathrm{~cm}$ - humic sand, stratified (charcoal at $57 \mathrm{~cm}$ ), peaty at the top

$87-100 \mathrm{~cm}$ - well decomposed peat with traces of gyttja

Profile 71, bottom of a small valley in its upper part (at spring niche)

0-20 cm - well decomposed sedge-moss peat, strongly watery

20-37 cm - dark brown well decomposed peat, compact, slightly sandy

$37-68 \mathrm{~cm}$ - dark grey sand with well decomposed peat

68-102 cm - brown peaty gyttja, compact, very silty

$102-130 \mathrm{~cm}$ - yellowish sand (humic intercalation at 121-124 cm)

Profile 118, valley bottom at the confluence of the two small valleys, near the barrow complex

0-7 cm - brown Juncus-moss peat

$7-15 \mathrm{~cm}$ - grey peaty mud

$15-31 \mathrm{~cm}$ - light grey sandy mud, strongly peaty (Sphagnum-sedge peat)

31-56 cm - dark brown Sphagnum-sedge peat, silty at the bottom

56-85 $\mathrm{cm}$ - Sphagnum-sedge peat, sandy at the bottom

85-92 cm - sand with organic matter

$92-100 \mathrm{~cm}-$ dark brown peat with gyttja

$100-110 \mathrm{~cm}$ - watery sand

Samples of $2 \mathrm{~cm}^{3}$ volume were taken from each core. Standard Erdtman's acetolysis method was applied preceded by removing carbonates with $10 \% \mathrm{HCl}$, boiling in $10 \%$ $\mathrm{KOH}$ and removing mineral particles in 40\% HF (BERGLUND, RALSKA-JASIEWICZOWA 1986). At least two slides were used for counting pollen spectra. The basic pollen sum for percentage calculations was about 500 pollen grains. It included trees and shrubs (AP), small shrubs and terrestrial herbaceous plants (NAP). Aquatic and reedswamp plants and Pteridophytes and Bryophytes were excluded from the basic sum. Pollen diagrams were drawn using POLPAL software (NALEPKA, WALANUS 2003). Local pollen assemblage zones (LPAZ) were distinguished on the basis of pollen curves of the main trees and NAP (WEST 1970; JANCZYK-KopIKowA 1987). The sediments from the bottom of cores 71 and 68a were radiocarbon dated at the Gliwice Radiocarbon Laboratory.

Plant macrofossil analysis was based on the examination of daub collected from features discovered at sites 9,6 and 3 situated in close vicinity of the pollen sites $68 \mathrm{a}, 68 \mathrm{~b}$ and 71 (Fig. 2). Outer surface of each daub piece was first cleaned with a soft brush and inspected under the low power microscope, next it was broken and smaller pieces were examined. The clay of the daub was porous and contained great admixture of sand, plant impressions were poorly preserved and indistinct. Besides imprints, the daub contained also a small number of charred fruits, seeds and wood charcoal pieces. In several features 
only the imprints of grass stems and leaves (probably straw remains) and of some other plants were present as well as small fragments of charred plant tissues.

Charcoal samples were collected in their visible concentrations. The number of samples in a particular grave or feature varied from one to seven. The anatomical structure of wood preserved in charcoals enabled their botanical identification. Each charcoal fragment was an observation unit and was manually broken along the three anatomical sections of wood: transverse, longitudinal tangential and longitudinal radial. Charcoal fragments were observed using a reflected light microscope with a maximum magnification of $500 \times$. Botanical identifications were possible with the use of anatomical atlases (e.g. SCHWEINGRUBER 1990) and with a modern reference collection from the W. Szafer Institute of Botany of the Polish Academy of Sciences. A Hitachi S-4700 scanning electron microscope (SEM) was also employed. This equipment belongs to the Laboratory of Field Emission Scanning Electron Microscopy and Microanalysis of the Institute of Geological Sciences at the Jagiellonian University in Krakow. Species were indicated only if solely one species from a genus occurs in the present-day flora of the region (LITYŃSKA-ZAJĄC, WASYLIKOWA 2005). The quantification method was based on fragment counts of charcoal remains (CHABAL 1997). However, in the case of handcollected samples there is a potential problem of the over-representation of taxa due to the fragmentation of larger charcoals. Therefore, mainly the ubiquities of taxa are taken into account when comparing the results of different archaeological features.

Furthermore, some dendrological observations were made in terms of indicating tree parts such as trunks, branches, and twigs. The classification of wood of small calibre was based on ring curvature (MARGUERIE, HuNOT 2007). Also, the evidence of biodeterioration of wood structure due to previous microbial attack or the presence of xylophagous organisms was noted (ThèrY-PARISOT 2001; MosKAL-DEL Hoyo et al. 2010).

\section{RESULTS}

\section{Pollen analysis}

Profile 71 (Fig. 5) is characterized by the distinct differentiation of pollen spectra and the occurrence of numerous palynological indicators of human activity which allowed to distinguish four local pollen assemblage zones (LPAZ, Tab. 1). Samples from the depth $105-50 \mathrm{~cm}$ contained a considerable amount of fine silt fraction which could not be removed during laboratory procedures and several undeterminable sporomorphs.

The continuous curves of Fagus sylvatica and Carpinus betulus pollen from the bottom of the profile indicate that biogenic sedimentation in the valley began in the Subboreal period (RALSKA-JASIEWICZOWA 2006; RALSKA-JASIEWICZOWA et al. 2004). This is confirmed by the radiocarbon date $3360 \pm 105 \mathrm{BP}$ GdS-1969 based on the analysis of a bulk sample from the depth 105-107 cm. The sedimentation started in a small reservoir surrounded by the reedswamp belt with Sparganium, Phragmites australis and Typha latifolia, which 


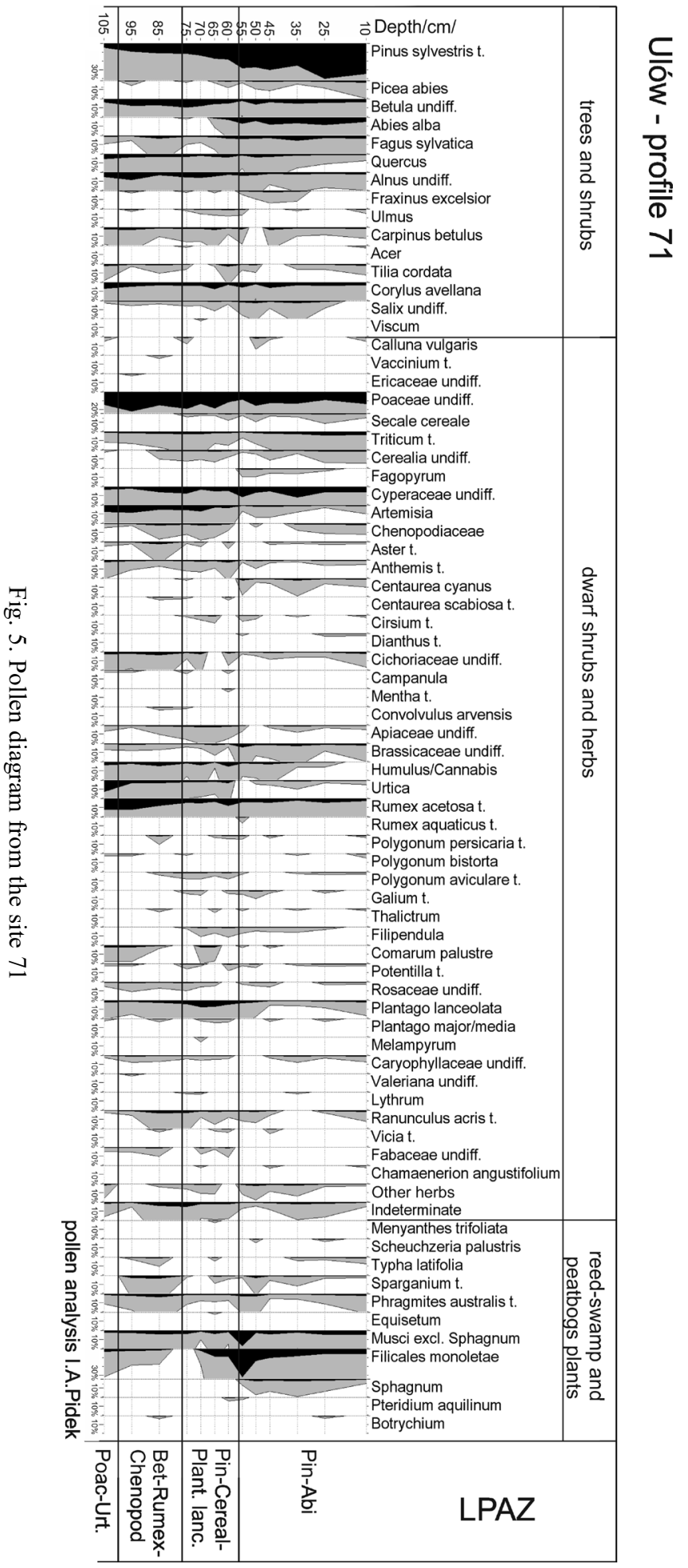


Table 1. Local pollen assemblage zones in profile Ulów 71

\begin{tabular}{|c|c|}
\hline $\begin{array}{l}\text { Local pollen } \\
\text { assemblage zone } \\
\text { and sample depth }\end{array}$ & Dominant and characteristic taxa \\
\hline $\begin{array}{l}\text { Poaceae- Urtica } \\
105 \mathrm{~cm}\end{array}$ & $\begin{array}{l}\text { NAP pollen predominates, mainly Poaceae, Urtica, Rumex acetosa, Artemisia, } \\
\text { Humulus/Cannabis and Cichoriaceae. Pinus, Betula, Quercus, Alnus and Corylus } \\
\text { form few percent curves; Salix, Carpinus, Fagus and Tilia are present. Phragmites } \\
\text { australis t. appears among the reedswamp plants. }\end{array}$ \\
\hline $\begin{array}{l}\text { Betula-Rumex- } \\
\text { Chenopodiaceae } \\
85-95 \mathrm{~cm}\end{array}$ & $\begin{array}{l}\text { NAP pollen predominates, compared to the preceding zone Urtica and Rumex ace- } \\
\text { tosa decrease, Aster t., Chenopodiaceae, Cyperaceae, Humulus/Cannabis, Apiaceae, } \\
\text { Ranunculus acris t. and Fabaceae increase. In the upper part Plantago lanceolata } \\
\text { increases, Thalictrum, Centaurea scabiosa, Polygonum persicaria and other taxa of } \\
\text { moist meadows appear. Continuous Triticum t. curve, the beginning of the continuous } \\
\text { Cerealia curve. Pollen curves of Pinus, Betula, Quercus, Fagus show no distinct } \\
\text { changes. Sparganium t. and Typha latifolia appear among the reedswamp plants. }\end{array}$ \\
\hline $\begin{array}{l}\text { Pinus-Cerealia- } \\
\text { Plantago lanceolata } \\
60-75 \mathrm{~cm}\end{array}$ & $\begin{array}{l}\text { Pinus curve increases up to 35\%, continuous but low Picea curve begins; continuous } \\
\text { Abies curve begins and reaches 5-6\% at the top. } \\
\text { Fagus, Quercus, Alnus have similar values as in the preceding zone, Tilia, Ulmus and } \\
\text { Fraxinus appear in low percentages. Continuous but low percentage curves of Secale } \\
\text { cereale (from zone bottom) and Fagopyrum and Centaurea cyanus (in the upper part) } \\
\text { appear. At the same time Brassicaceae curve increases, those of Aster t., Cichoriaceae, } \\
\text { Apiaceae, Urtica, Comarum palustre, Fabaceae and Plantago lanceolata decrease. } \\
\text { In the upper part curves of Musci and Filicales rise and Sphagnum appears. }\end{array}$ \\
\hline $\begin{array}{l}\text { Pinus-Abies } \\
10-55 \mathrm{~cm}\end{array}$ & $\begin{array}{l}\text { The dominance of Pinus up to } 40 \% \text {, Abies increases up to } 10 \% \text {; Fagus, Quercus, } \\
\text { Alnus and Picea form low but continuous curves; continuous curves of Poaceae, } \\
\text { Cyperaceae, Rumex acetosa t., Fagopyrum and Centaurea cyanus, increased per- } \\
\text { centages of Secale cereale, Triticum t. and Cerealia. Decreased numbers of moss } \\
\text { spores (including Sphagnum). }\end{array}$ \\
\hline
\end{tabular}

is indicated by pollen spectra from the depth $105-70 \mathrm{~cm}$. Woodlands included patches of oak-hornbeam forests (Quercus, Tilia, Carpinus), beech forests (Fagus) and alder cars (with the dominance of Alnus and the admixture of Fraxinus). The high NAP percentages including the dominance of Poaceae, Artemisia and Rumex t. acetosa and continuous curves of e.g. Chenopodiaceae indicate that open areas played a significant role in the surroundings of the site. Pollen of cereals (Triticum t., Cerealia undiff.) and pasture indicators were present. Significant number of plants considered by BeHRE (1981) as indicators of pasturage carried out on moist meadows (Plantago lanceolata, Plantago major/media, Apiaceae, Ranunculus, Cichoriaceae) suggests that domestic animals grazed mainly on such habitats. Drier habitats (Campanula) and forests (e.g. Melampyrum pratense) were probably also used for pasturage (BEHRE 1981; LATALOWA 2003).

Samples from $65-25 \mathrm{~cm}$ depth originate from a peat-bog, probably from a fen. This is indicated by the higher percentages of moss spores, continuous Sphagnum curve and the appearance of Menyathes trifoliata and Scheuchzeria palustris. Reedswamp with Sparganium still covered the bog shore. At that time forest vegetation underwent significant changes caused by the appearance of fir which probably expanded over most of the areas hitherto occupied by wet alder woods and moister forms of oak- 
hornbeam forests. Pine communities spread on poorer habitats. The presence of Abies indicates that this section of pollen profile represents the Subatlantic period. Open areas were occupied by cereal fields (presence of Secale cereale, Triticum t. and Cerealia pollen), meadows and pastures. The decrease of several herbaceous plant pollen in the middle of the Pinus-Cerealia-Plantago lanceolata LPAZ (e.g. Plantago lanceolata, Cichorioideae and Apiaceae) indicates that the area of pastures probably diminished compared to the older period. The occurrence of Cannabis type pollen grains besides those typical for Humulus lupulus suggests that hemp was cultivated in the vicinity of the site. The beginning of the continuous Fagopyrum curve at $55 \mathrm{~cm}$ depth allows to date the whole upper part of peat to the early Middle Ages (LityŃsKa-ZajĄC, WasYLIKOWA 2005, p. 112). Fagopyrum curve is accompanied by the beginning of the continuous Centaurea cyanus curve and the continuation of Secale cereale and Humulus/ Cannabis curves. These pollen spectra point to the existence of a hiatus below $55 \mathrm{~cm}$ depth which covered a considerable part of the Subatlantic period.

In profile 118 (Fig. 6) sporomorphs on the whole were well preserved but some badly damaged undeterminable specimens occurred in several samples. Besides, in many samples fine clay was present which could not be removed during sample preparation. Four LPAZ were distinguished in this profile (Tab. 2).

The presence of Carpinus betulus and Fagus sylvativa indicates that the sedimentation started not later than Subboreal period, as in profile 71. Various types of forest and meadow communities dominated in the landscape. At first (LPAZ Betula-QuercusPoaceae) forests with oak, lime and hornbeam trees were growing in the surroundings of the site, as well as wet alder woods with ash and elm. Beech could be an admixture in oak-hornbeam forests, spruce could grow in moister woods. Birch played an important role in the landscape, growing on the waste land or at forest outskirts. The occurrence of Fagopyrum, Triticum and Cerealia pollen creates some problems in interpretation. While cereals could have been cultivated at that time the appearance of Fagopyrum pollen must be the result of contamination. This is stressed by the fact that in the overlying zone Betula-Carpinus buckwheat pollen is absent while Cerealia pollen appears sporadically. Oak-hornbeam forests became enriched in maple, beech appeared more frequently. Wet alder woods did not change or even increased their stands. The increase of hornbeam curve in the upper part of the Betula-Carpinus zone may reflect forest regeneration. The occurrence of Nuphar pollen indicates the existence of open water which was surrounded by the belt of reedswamp and the bog.

LPAZ Pinus-Fagus-Sphagnum illustrates the next stage of forest transformation during which fir appeared, the role of beech increased while the area covered by oakhornbeam forests with an admixture of lime diminished. The fall of Alnus curve indicates that habitats of wet alder woods became limited. Moist meadows played significant role in the landscape. The mire had the character of a fen or a raised bog. Except for a small number of pasturage indicators in this zone there are no other indicators of human activity. One could speculate that the occurrence of Pteridium aquilinum spores could be such an indicator because this fern produces large number of spores after fires. The occurrence of fir indicates that this zone can be dated to Subatlantic period. 


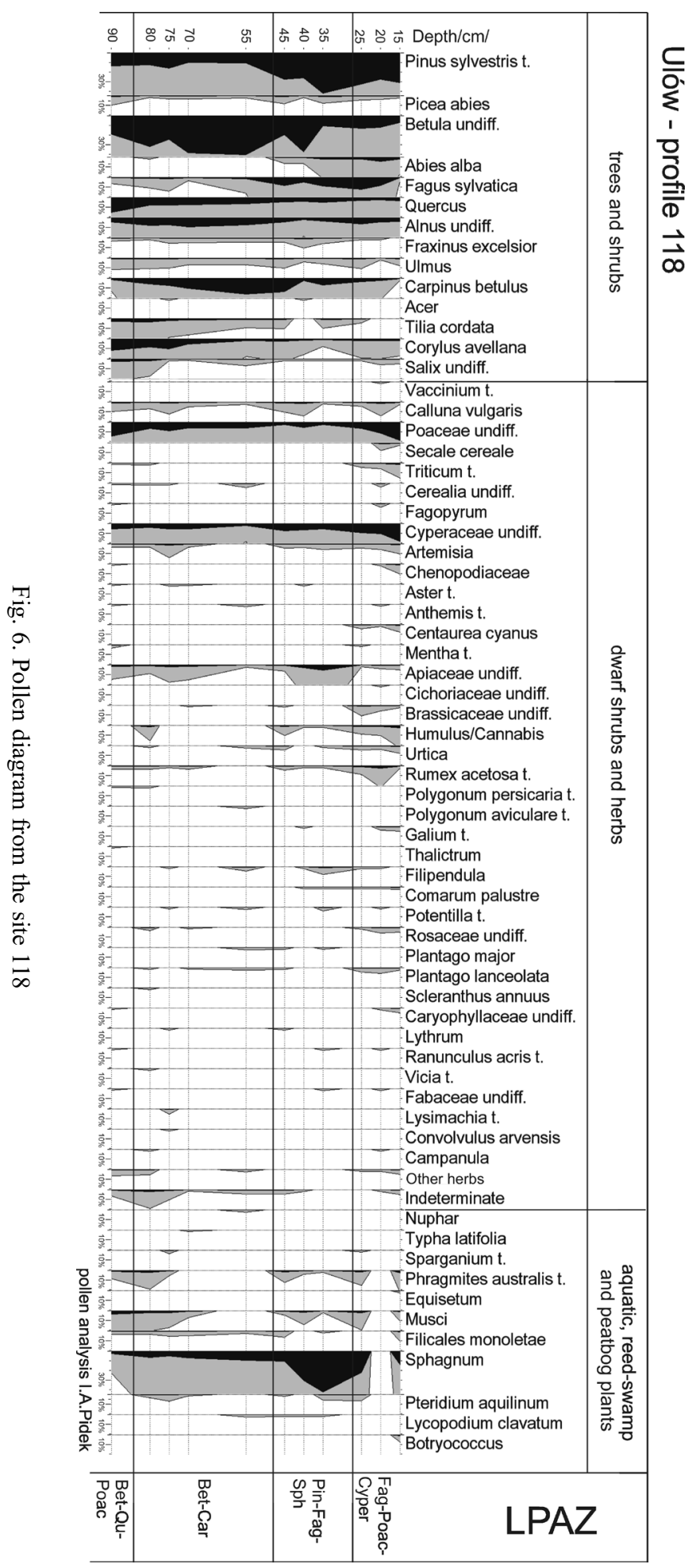


Table 2. Local pollen assemblage zones in profile Ulów 118

\begin{tabular}{|c|c|}
\hline $\begin{array}{l}\text { Local pollen } \\
\text { assemblage zone } \\
\text { and sample depth }\end{array}$ & Dominant and characteristic taxa \\
\hline $\begin{array}{l}\text { Betula-Quercus- } \\
\text { Poaceae } \\
90 \mathrm{~cm}\end{array}$ & $\begin{array}{l}\text { Pollen of trees and shrubs dominates, mainly Betula up to } 30 \% \text {, Quercus up to } \\
15 \% \text {, Corylus up to } 12 \% \text {; higher percentages of Tilia, Salix, Alnus, Carpinus, } \\
\text { lower of Picea, Fagus, Fraxinus, Ulmus. Among the NAP Poaceae curve is the } \\
\text { highest. Plants of wet meadows are present: Cyperaceae, Apiaceae, Polygonum } \\
\text { persicaria and Ranunculus acris t. Single pollen grains of Cerealia, Triticum t. } \\
\text { and Fagopyrum are present. Among the reedswamp plants Phragmites australis t. } \\
\text { occurs. Small numbers of moss spores, including Sphagnum are present. }\end{array}$ \\
\hline $\begin{array}{l}\text { Betula-Carpinus } \\
55-80 \mathrm{~cm}\end{array}$ & $\begin{array}{l}\text { Betula pollen dominates reaching up to } 40 \% \text {, Carpinus increases toward the top and } \\
\text { reaches } 15 \% \text {, Corylus declines. Alnus and Quercus curves are relatively high, Fagus, } \\
\text { Fraxinus, Ulmus, Tilia and Salix form continuous but low pollen curves. Pinus and } \\
\text { Picea curves do not change compared to the preceding zone. Number of the NAP } \\
\text { taxa increases including plants of moist meadows e.g. Filipendula, Potentilla, Lythrum } \\
\text { and pastures e.g. Plantago lanceolata. Single Cerealia pollen grains appear. Scattered } \\
\text { grains of reedswamp plants (Typha latifolia, Sparganium, Phragmites australis t.) } \\
\text { and aquatics (Nuphar) are present. Percentages of Sphagnum spores increase. }\end{array}$ \\
\hline $\begin{array}{l}\text { Pinus-Fagus- } \\
\text { Sphagnum } \\
35-45 \mathrm{~cm}\end{array}$ & $\begin{array}{l}\text { Pinus percentages increase up to } 40 \%, \text { Fagus curve rises up to } 10 \% \text {, continuous } \\
\text { Abies curve begins. Betula, Carpinus and Tilia decline. The curves of Cyperaceae, } \\
\text { Apiaceae, Humulus/Cannabis, Filipendula and Rumex acetosa t. increase. Comarum } \\
\text { palustre pollen appears, Sphagnum curve is very high, Pteridium aquilinum spores } \\
\text { form almost continuous curve. Percentages of Plantago lanceolata pollen decrease, } \\
\text { the absence of Cerealia pollen is noticeable. }\end{array}$ \\
\hline $\begin{array}{l}\text { Fagus-Poaceae- } \\
\text { Cyperaceae } \\
15-25 \mathrm{~cm}\end{array}$ & $\begin{array}{l}\text { Pinus pollen curve is high, Fagus remains at the relatively high level, Abies slightly } \\
\text { increases. Pollen percentages of other trees resemble those from the preceding } \\
\text { zone. NAP pollen distinctly rises, mainly of Poaceae and Cyperaceae. Cerealia } \\
\text { pollen appears frequently, including Secale cereale, Triticum t. and Fagopyrum. } \\
\text { Centaurea cyanus is constantly present. Moss spores decrease in number. }\end{array}$ \\
\hline
\end{tabular}

The topmost part of the diagram (Fagus-Poaceae-Cyperaceae LPAZ) dominated by pine pollen and numerous indicators of human activity reflects vast areas of open vegetation in which pine pollen can distributed widely. Beech curve shows a distinct increase and fir curve slightly rises suggesting development of beech and fir communities. Cereal pollen is continuously present (Triticum t., Secale, Cerealia), as well as that of Brassicaceae, cereal weeds (e.g. Centaurea cyanus) and nitrophilous plants growing in ruderal habitats (e.g. Urtica). Fagopyrum pollen indicates that this zone represents the early Middle Ages. It corresponds to the upper part of the zone PinusCerealia-Plantago lanceolata and the topmost zone Pinus-Abies in the profile 71.

In the profiles $68 \mathrm{a}$ and $68 \mathrm{~b}$ only one pollen zone (Tab. 3, Pinus-Poaceae-Cyperaceae LPAZ) is recorded. The differences between individual pollen spectra are insignificant and pollen zones in both profiles are much the same. They reflect an open landscape dominated by cultivated fields and moist meadows (including pastures) with small forest patches. Landscape openness is indicated by high percentages of pine pollen which may partly originate from a long distance transport. Locally, besides pine woods 
Table 3. Local pollen assemblage zones in profiles Ulów $68 \mathrm{a}$ and $68 \mathrm{~b}$

\begin{tabular}{|l|l|}
\hline $\begin{array}{l}\text { Local pollen } \\
\text { assemblage zone }\end{array}$ & \multicolumn{1}{|c|}{ Dominant and characteristic taxa } \\
\hline $\begin{array}{l}\text { Profile 68a } \\
\text { Pinus-Poaceae- } \\
\text { Cyperaceae }\end{array}$ & $\begin{array}{l}\text { Pinus pollen predominates at the level of 39-56\%; Abies, Fagus, Quercus, Fraxinus, } \\
\text { Alnus, Ulmus, Picea and Salix pollen curves below 10\%. Poaceae and Cypera- } \\
\text { ceae have the highest percentages among the NAP. Urtica, Rumex acetosa t. and } \\
\text { Artemisia appear abundantly. Secale cereale, Triticum t., Cerealia undiff. and } \\
\text { Fagopyrum are present. Among the reedswamps Phragmites australis t., Sparga- } \\
\text { nium and Equisetum are recorded. }\end{array}$ \\
\hline $\begin{array}{l}\text { Profile 68b } \\
\text { Pinus-Poaceae- } \\
\text { Cyperaceae }\end{array}$ & $\begin{array}{l}\text { Predominance of Pinus pollen ca. 44-47\%; Abies, Fagus, Quercus, Fraxinus, Alnus, } \\
\text { Ulmus, Picea } \text { and Salix constantly present below 10\%. Poaceae and Cyperaceae } \\
\text { have the highest percentages among the NAP. Artemisia, Brassicaceae, Humulus } \\
\text { and Rumex acetosa } \text { t. are fairly numerous; Secale cereale, Triticum, Cerealia undiff. } \\
\text { and Fagopyrum are constantly present. Centaurea cyanus appears among the field } \\
\text { weeds. Phragmites australis t. and Sparganium appear among the reedswamps }\end{array}$ \\
\hline
\end{tabular}

there occur also deciduous forests with oak, hornbeam and lime as well as beechand fir-woods. The presence of fir indicates the Subatlantic age of this zone in both profiles. Coring places were surrounded by a reedswamp, numerous ferns and mosses (including Sphagnum) were growing in the neighbourhood. Pollen spectra from both cores correspond to the topmost zones in profiles 71 and 118 and the occurrence of Fagopyrum pollen indicates their Early Medieval age.

\section{Fruits and seeds}

The most numerous plant macrofossils were recovered from site 9 from the Wielbark culture settlement dated to the Roman Period (Tab. 4). 41 features of this culture were studied and 89 samples from the layer connected with them. In total, 2271 daub pieces were examined, including 1618 from features and 653 from the layer. Only 23 features contained remnants which were identified with different accuracy: fruits or seeds appeared in 14 features, in 9 only leaves and stems of grasses (straw) were found. Only 193 daub pieces from the layer contained plant remnants. Daub pieces were small, the longest dimension did not exceed $5 \mathrm{~cm}$, in a few cases reached $25 \mathrm{~cm}$.

At site 6 plant material was recovered from one semi-dugout dated to the late Roman or the early phase of the Migration period (Tab. 5). In total, 54 daub pieces from the dugout were examined (only 34 of them contained plant fragments) and 37 from the layer (the only plant remnants were straw fragments found in 13 daub pieces). Daub pieces were small, the longest dimension was up to $6 \mathrm{~cm}$.

The material examined from site 3 originated from 15 features but only three of them, namely features 81,84 and 95 were dated to the Roman or early Migration period (Tab. 6). 297 small daub pieces from these features were examined, their longest dimension was below $5 \mathrm{~cm}$, exceptionally up to $8 \mathrm{~cm}$. The chronology of the remaining 12 features was not established and for this reason the samples collected from them and from the layer are not included in this article. 
Cereals were represented in daub by barley, millet and a wheat species. Barley (Hordeum vulgare) was found in 4 features at site 9, one feature at site 6 and 2 features at site 3. It was represented mainly by the imprints of single hulled grains, in addition a few imprints of triplets and ear axis fragments and one imprint of an ear fragment were found. Charred barley remains included 2 caryopses and 5 fragments of ear axis. Millet (Panicum miliaceum) was recovered from all sites, first of all as imprints of hulled grains (over 110 specimens), a few imprints of palaea or lemma and 3 charred grains were also found. In one daub piece from a post hole (site 9, feature 2A) an accumulation of millet grains was discovered; they were arranged irregularly, on the one plane 16 specimens were counted but their actual number must have been higher. Wheat was present at all three sites but in much smaller numbers. In feature 2, site 9 , one spikelet imprints was preserved which could belong to emmer (Triticum dicoccon) or einkorn wheat (T. monococcum). The majority of imprints of wheat spikelet, glume and ear axis fragments could not be identified to the species level but the occurrence of impressions of wheat glumes in all three sites suggests that they belonged to a hulled wheat. Besides, in all sites the imprints of undetermined cereals (Cerealia indet.) were present. Many daub pieces contained a small number of impressions of grass leaves and culms which probably were the remnants of straw (Cerealia/Poaceae in Tables).

Wild herbaceous plants preserved in daub belonged to 24 taxa of various rank, including 16 species (sites 9 and 3, Tabs 4 and 6). They were represented usually by single charred diasporas, very few taxa were preserved as imprints: 1 seed of a species from Caryophyllaceae family, 1 seed of Melandrium sp., 1 caryopsis of Echinochloa crus-galli, 1 caryopsis of Setaria viridis/S. verticillata, 1 glume of $S$. pumila, 1 caryopsis of cf. Lolium perenne and grains and glumes of unknown grass species (Poaceae). A very rare finds were small fragments of charred moss branches recovered in features 47 and 62, site 9, which could not be determined more precisely. Perhaps mosses were used for some purpose, e.g. wall tightening.

The daub from all sites contained very small fragments of wood charcoal. A few larger pieces from site 9 belonged to Abies alba, Fraxinus excelsior, Acer sp., Betula sp., Quercus sp. and probably cf. Tilia sp.

The impressions of undetermined seeds/fruits were rare, slightly more frequent were small charred fragments of unknown plant tissues and relatively numerous were imprints of grass leaves and stems, probably coming from cereal straw.

\section{Wood charcoal}

Samples of wood charcoals were collected at sites 3, 6, and 9. At site 3 three samples were taken from features 81 and 84 dated to the Roman Period. Birch Betula sp. remnants were found in feature 81, those of Scots pine Pinus sylvestris and hornbeam Carpinus betulus in feature 84. In addition, wood charcoals were collected also from the Wielbark culture graves. However, because in several features of this multicultural site the considerable mixing of archaeological material (including plants) of different age was documented, the results of anthracological investigations discussed 


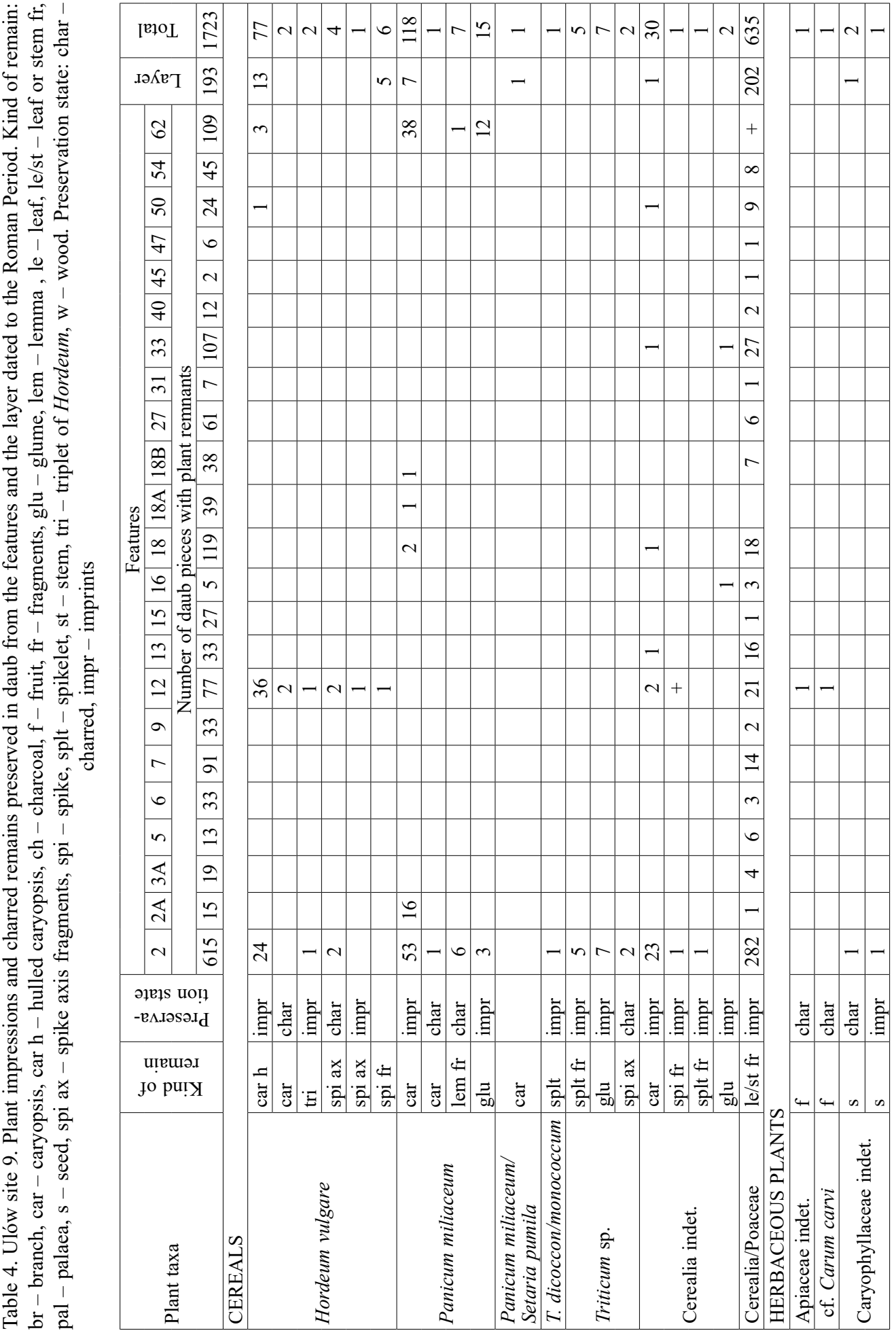


Plant exploitation by the inhabitants of the Wielbark culture settlement complex...

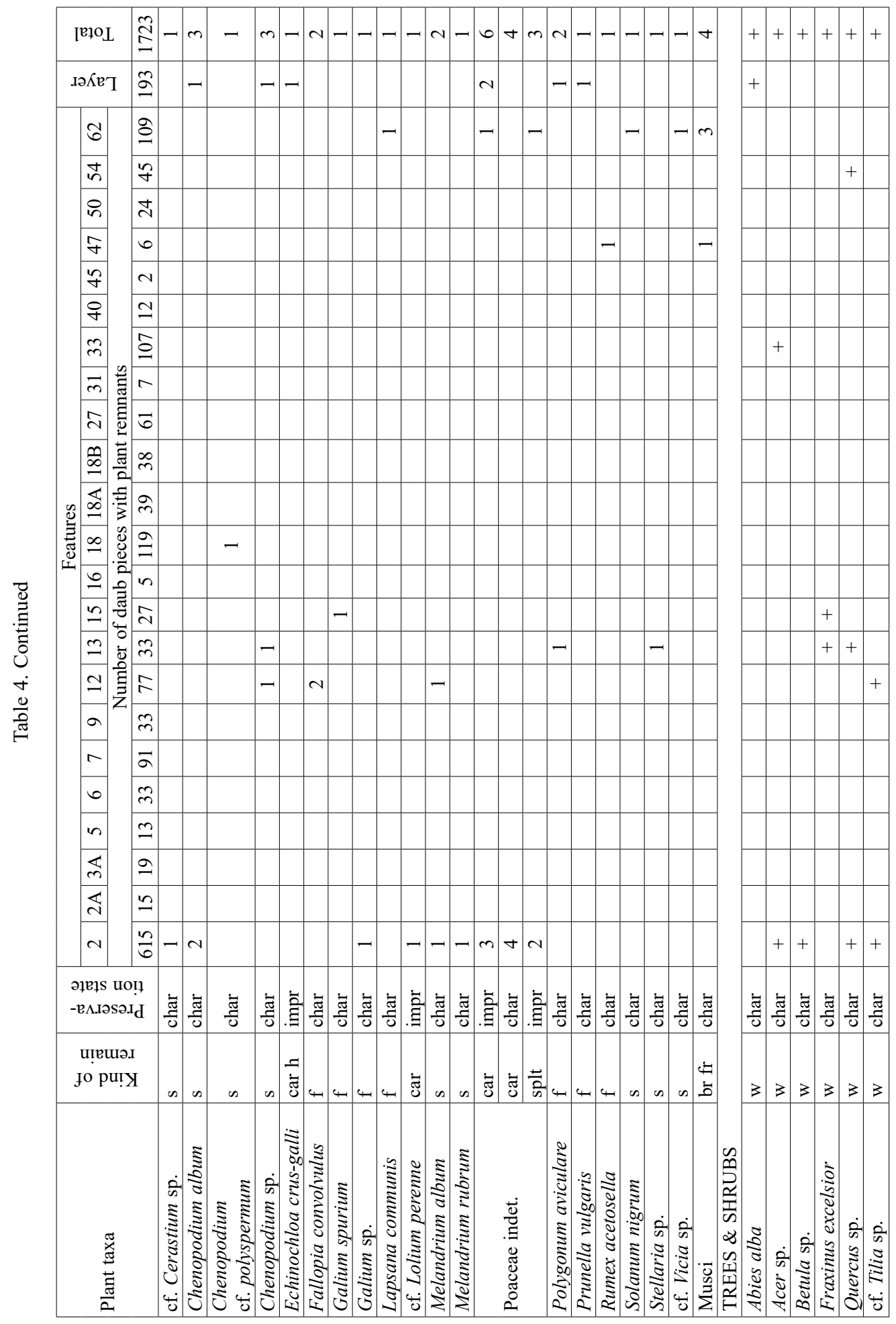


Table 5. Ulów site 6. Plant impressions and charred remains preserved in daub from a semi-dugout dated to the Roman or Early Migration period. Explanations as in Table 4

\begin{tabular}{|c|c|c|c|c|c|}
\hline \multirow{3}{*}{ Plant taxa } & \multirow{3}{*}{$\begin{array}{l}\text { Kind of } \\
\text { remain }\end{array}$} & \multirow{3}{*}{$\begin{array}{c}\text { Preservation } \\
\text { state }\end{array}$} & Feature 1 & \multirow[b]{2}{*}{ Layer } & \multirow[b]{2}{*}{ Total } \\
\hline & & & $\begin{array}{l}\text { Number of daub pieces } \\
\text { with plant remnants }\end{array}$ & & \\
\hline & & & 34 & 13 & 47 \\
\hline Hordeum vulgare & car & impr & 5 & & 5 \\
\hline Panicum miliaceum & car & char & 2 & & 2 \\
\hline Triticum $\mathrm{sp}$. & glu & impr & 1 & & 1 \\
\hline Cerealia/Poaceae & le/st & impr & 20 & 6 & 26 \\
\hline Poaceae indet. & car & impr & 1 & & 1 \\
\hline
\end{tabular}

Table 6. Ulów site 3. Plant impressions and charred remains preserved in daub from the Roman Period features. Explanations as in Table 4

\begin{tabular}{|c|c|c|c|c|c|c|}
\hline \multirow{4}{*}{ Plant taxa } & \multirow{4}{*}{$\begin{array}{l}\text { Kind of } \\
\text { remain }\end{array}$} & \multirow{4}{*}{$\begin{array}{l}\text { Preservation } \\
\text { state }\end{array}$} & \multicolumn{3}{|c|}{ Features } & \multirow{3}{*}{ Total } \\
\hline & & & 81 & 84 & 95 & \\
\hline & & & \multicolumn{3}{|c|}{$\begin{array}{c}\text { Number of daub pieces with } \\
\text { plant remnants }\end{array}$} & \\
\hline & & & 14 & 84 & 199 & 297 \\
\hline \multirow{2}{*}{ Hordeum vulgare } & car & impr & 1 & 1 & & 2 \\
\hline & tri & impr & 1 & & & 1 \\
\hline Panicum miliaceum & glu & impr & & 1 & & 1 \\
\hline Triticum sp. & glu & impr & 1 & & & 1 \\
\hline Cerealia indet. & car & impr & & 5 & & 5 \\
\hline Cerealia/Poaceae & le/st fr & impr & 8 & 51 & 4 & 63 \\
\hline Melandrium album & $\mathrm{s}$ & impr & & 1 & & 1 \\
\hline Setaria pumila & pal & impr & & 1 & & 1 \\
\hline Setaria viridis/verticillata & car & impr & & 1 & & 1 \\
\hline
\end{tabular}

here concern only graves which contained charcoals radiocarbon dated to the Wielbark culture (MosKal-DEL HoYo et al. 2017).

Among 245 charcoal fragments found in 26 samples collected from 11 graves, 12 taxa were found: fir Abies alba, juniper Juniperus communis, Scots pine Pinus sylvestris, maple Acer sp., alder Alnus sp., birch Betula sp., hornbeam Carpinus betulus, hazel Corylus avellana, beech Fagus sylvatica, ash Fraxinus excelsior, oak Quercus sp., and willow Salix sp. or poplar Populus sp. (Selected taxa in Fig. 7; Tab. 7). The dominance of birch was observed (Fig. 8: A), both in number of fragments and their ubiquity. Pine was also widespread as its remains were found in 6 features. Other taxa were less abundant or uncommon. In addition, wood of trunks was present. Some fragments showed the presence of xylophagous organisms, mainly fungi (Fig. 7: C). Therefore, it is likely that they could have come from deadwood. Bark fragments were found in two graves. These observation might indicate that wood of different condition and calibre was gathered and used for funerary purpose. 

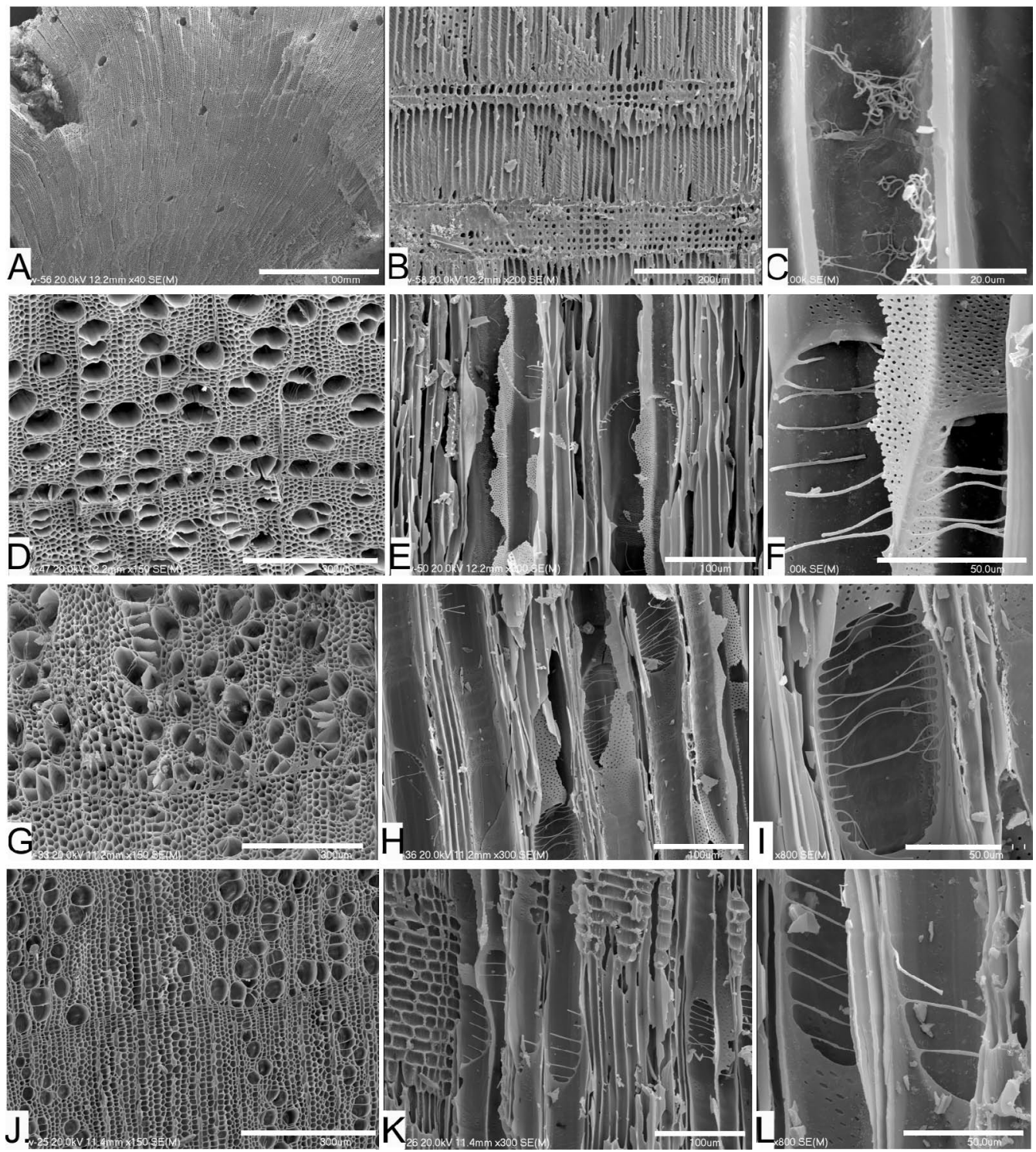

Fig. 7. Selected charcoals from the archaeological site 3 in Ulów. A - Pinus sylvestris, transverse section (TS), scale bar: $1.00 \mathrm{~mm}, \mathrm{~B}-$ P. sylvestris, longitudinal radial section (RLS), scale bar: $200 \mu \mathrm{m}, \mathrm{C}-P$. sylvestris, RLS with fungal hyphae, scale bar: $20 \mu \mathrm{m}, \mathrm{D}$ - Betula sp., TS, scale bar: $300 \mu \mathrm{m}, \mathrm{E}-$ Betula sp., RLS, scale bar: $100 \mu \mathrm{m}, \mathrm{F}-$ Betula sp., RLS, scale bar: $50 \mu \mathrm{m}, \mathrm{G}-$ Alnus sp., TS, scale bar: $300 \mu \mathrm{m}$, $\mathrm{H}$ - Alnus sp., RLS, scale bar: $100 \mu \mathrm{m}$, I - Alnus sp., RLS, scale bar: $50 \mu \mathrm{m}, \mathrm{J}-$ Corylus avellana, TS, scale bar: $300 \mu \mathrm{m}, \mathrm{K}-$ C. avellana, RLS, scale bar: $100 \mu \mathrm{m}, \mathrm{L}-$ C. avellana, RLS, scale bar: $50 \mu \mathrm{m}$. Micrographs: M. Moskal-del Hoyo

In charcoal assemblage from Ulów site 9, a total of 34 samples from 13 archaeological pits were investigated (Tab. 8). This assemblage probably represents remains of fuel wood gathered in the vicinity of the settlement. Taking into account the number 


\begin{tabular}{|c|c|c|c|c|c|c|c|c|c|c|c|c|c|c|c|c|c|c|c|c|c|c|c|}
\hline \multicolumn{2}{|c|}{$\partial^{0}$} & $\stackrel{+}{0}$ & $\stackrel{+}{0}$ & $\stackrel{\vec{v}}{\mathrm{i}}$ & $\begin{array}{l}\infty \\
0 \\
0\end{array}$ & $\begin{array}{l}\infty \\
0 \\
0\end{array}$ & $\stackrel{+}{\circ}$ & $\stackrel{+}{\stackrel{d}{~}}$ & $\stackrel{+}{\circ}$ & $\stackrel{m}{n}$ & 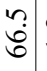 & 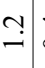 & $\dot{0}$ & 0 & 0 & 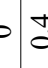 & 8 & & & & & & \\
\hline \multicolumn{2}{|c|}{$\begin{array}{l}\text { słuəuôt..l } \\
\text { jo uns }\end{array}$} & - & - & 6 & $\sim$ & $N$ & - & in & - & $\cong$ & $\hat{6}$ & $m$. & $-c$ & 0 & 00 & $D-$ & $\mid \stackrel{\sim}{\stackrel{\sim}{v}}$ & & & & & & \\
\hline \multirow{2}{*}{ 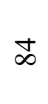 } & $\vec{G}$ & & & & - & & & -1 & & & & & & & & & $N$ & $\sim$ & & & & & - \\
\hline & ஓे & & & & & & & $\infty$ & & & & & & & & - & $1 a$ & - & & & - & & - \\
\hline \multirow{5}{*}{ ๗ } & $\stackrel{\infty}{\infty}$ & & & $m$ & & & & & & & $\Xi$ & & & & & & $\stackrel{\sim}{i}$ & $\sim$ & & & in & & - \\
\hline & $\frac{n}{m}$ & & - & - & & & & & & $N$ & $\stackrel{0}{-1}$ & & & & & & 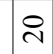 & $\nabla$ & & & $m$ & & - \\
\hline & $\stackrel{\nabla}{m}$ & & & & & & & & & $N$ & $\beth$ & & & & & & $\vec{\sim}$ & $\sim$ & - & & 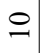 & & $n$ \\
\hline & $\underset{\infty}{\vec{m}}$ & & & - & & & & & & $r$ & $=$ & & - & & & & $\stackrel{\sim}{~}$ & $\nabla$ & & & $n$ & & $r$ \\
\hline & 之 & & & & & & & & - & - & 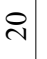 & & & & & & ก & $m$ & - & & $N$ & & \\
\hline 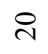 & $\begin{array}{l}\infty \\
\stackrel{\sim}{N}\end{array}$ & & & & & & & & & & $\sim$ & & & & & & $r$ & & & & & & \\
\hline I & 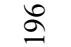 & & & & & & - & & & & - & $N$ & & & & & $\nabla$ & $m$ & & -1 & & $N$ & - \\
\hline \multirow{2}{*}{$\Xi$} & I & & & & & - & & 의 & & & . & & & & & & $=$ & $\sim$ & & & $m$ & & \\
\hline & $\stackrel{\infty}{=}$ & - & & & - & & & $m$ & & & $N$ & & & & & & $r$ & $\nabla$ & & & $\sim$ & & \\
\hline \multirow{2}{*}{$\simeq$} & $\Xi$ & & & & & & & - & & & $m$ & & & & & & $\nabla$ & $\sim$ & & & & & \\
\hline & $\stackrel{0}{=}$ & & & & & & & & & & $N$ & & & & & & $N$ & - & & & $N$ & & \\
\hline \multirow{2}{*}{ ๓a } & \& & & & & & & & - & & & 0 & & & & & & $r$ & $N$ & & & - & & \\
\hline & ભે & & & & & & & $\nabla$ & & & $\Xi$ & & & & & & $\infty$ & $N$ & & & $m$ & & - \\
\hline \multirow{2}{*}{ ঝ } & $\hat{a}$ & & & & & & & & & & 6 & & & & & & 0 & - & & & - & & \\
\hline & $\approx n$ & & & & & & & $N$ & & & $N$ & - & & & & & in & $m$ & & & $N$ & & \\
\hline$n$ & $\approx$ & & & - & & - & & & & & . & & & & & & $N$ & $N$ & & & -1 & - & \\
\hline$\nabla$ & $\stackrel{ }{=}$ & & & & & & & & & & 6 & & & & & & 6 & - & & $\sim$ & & & - \\
\hline \multirow{7}{*}{$m$} & J & & & & & & & - & & & $\approx$ & & & & & & \pm & $N$ & & -1 & $\sim$ & & \\
\hline & $\kappa$ & & & & & & & $\nabla$ & & - & a & & & & & & $\Xi$ & $m$ & & & - & & - \\
\hline & $\stackrel{n}{\sim}$ & & & & & & & $\nabla$ & & & & & & & & & $\nabla$ & - & & & - & & \\
\hline & $\hat{n}$ & & & & & & & $N$ & & & $N$ & & & & & & $\nabla$ & $N$ & & & $N$ & & $N$ \\
\hline & $\tilde{n}$ & & & & & & & $\nabla$ & & & $N$ & & & & & & 6 & $N$ & & & - & & \\
\hline & $\vec{n}$ & & & & & & & $n$ & & & $\nabla$ & & & & & & $a$ & $N$ & & & & & \\
\hline & $\stackrel{\vartheta}{\forall}$ & & & & & & & & & & - & & & & & & - & - & & & & & \\
\hline 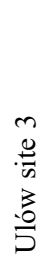 & 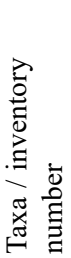 & 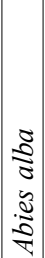 & 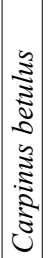 & 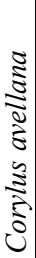 & 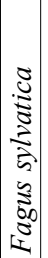 & 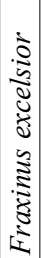 & 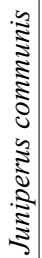 & 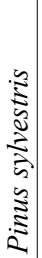 & $\begin{array}{l} \\
\dot{2} \\
\overline{8} \\
\frac{8}{7}\end{array}$ & 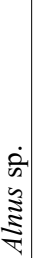 & 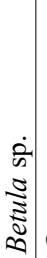 & 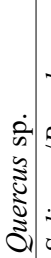 & 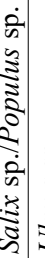 & 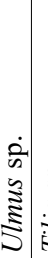 & 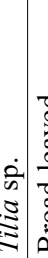 & 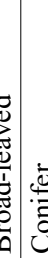 & 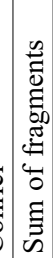 & 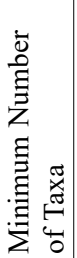 & 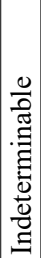 & 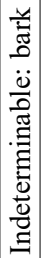 & 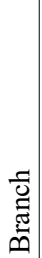 & $\frac{.}{\Xi}$ & 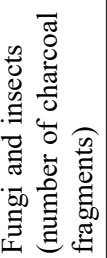 \\
\hline
\end{tabular}



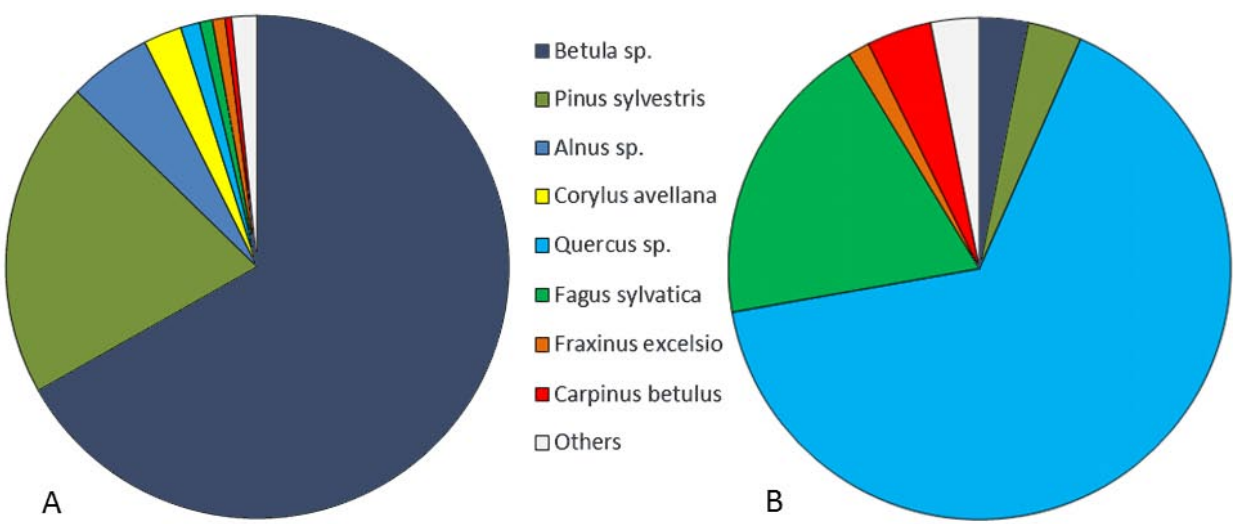

Fig. 8. Relative frequencies of the main taxa found in charcoal assemblages from the Wielbark culture. Data from the cemetery of Ulów, site 3 (A) and the settlement of Ulów, site 9 (B)

of charcoal fragments, oak is the most abundant taxon, followed by beech, hornbeam, pine, and birch (Fig. 7: B). Other occasionally found taxa include: ash, poplar, common juniper, and fir. Oak was also the most frequent when the ubiquity of taxa in samples is considered. Hornbeam, beech, pine, and birch are ubiquitous taxa. The taxonomic list is very similar in the settlement and the cemetery, but there is a discrepancy between predominating taxa since birch is the most frequent taxon at the cemetery and oak in the settlement.

\section{DISCUSSION AND CONCLUSIONS}

Holocene history of the Middle Roztocze vegetation is relatively well known thanks to pollen diagrams from the sites Tarnawatka, Krasnobród and Hamernia reaching back to the Allerød period and the short diagram from Kosobudy (Fig. 1) covering only the early Middle Ages (BALAga 1998; MargielewsKi et al. 2015). Vegetation changes in the northern part of the Eastern Roztocze are illustrated in pollen diagram from Kobyle Jezioro (Fig. 1; KorzeŃ et al. 2015) encompassing the Subboreal and Subatlantic time. The results of these investigations were a good reference material for the interpretation of both profiles from Ulów.

In the surroundings of Ulów, as in the other parts of the Roztocze, the spread of Carpinus betulus and Fagus sylvatica took place in the Subboreal (the two lowermost LPAZ in profiles 71 and 118). Local forest stands of that period were composed of oak, hornbeam and lime trees with an admixture of beech and spruce. Moist habitats were overgrown by forests with alder, ash and elm. Local differences between various forest stands are indicated for instance by the greater role of birch, hornbeam, elm and ash near the site 118 compared to 71 .

The Subatlantic period was marked by the spread of fir (Abies alba) in the Middle (Tarnawatka, Krasnobród, Hamernia: BALAga 1998; MARGIELEwSKI et al. 2015) and 
Table 8. Results of the anthracological analysis from the archaeological features of the Wielbark culture from Ulów, site 9

\begin{tabular}{|c|c|c|c|c|c|c|c|c|c|c|c|c|c|c|c|}
\hline \multirow{2}{*}{$\begin{array}{l}\text { Ulów site } 9 \\
\text { Taxa / inventory number }\end{array}$} & \multirow{2}{*}{$\begin{array}{c}7 \\
88\end{array}$} & \multirow{2}{*}{\begin{tabular}{l|l}
9 \\
83
\end{tabular}} & \multicolumn{2}{|c|}{15} & \multirow{2}{*}{\begin{tabular}{|c|}
22 \\
P32 \\
\end{tabular}} & \multirow{2}{*}{$\begin{array}{l}23 \\
597\end{array}$} & \multirow{2}{*}{$\begin{array}{ll}25 \\
\mathrm{P} 27\end{array}$} & \multicolumn{6}{|c|}{26} & \multirow{2}{*}{\begin{tabular}{l|l|}
27 \\
605
\end{tabular}} & \multirow{2}{*}{\begin{tabular}{|l|}
53 \\
748
\end{tabular}} \\
\hline & & & 214 & 213 & & & & 602 & 603 & 664 & 575 & 639 & 755 & & \\
\hline \multicolumn{16}{|l|}{ Abies alba } \\
\hline Carpinus betulus & 1 & 1 & & & 1 & & & & & & & & & & \\
\hline Fagus sylvatica & & & & & & & & & 1 & & & & & & \\
\hline Fraxinus excelsior & & & & & & & & & & & & & & 1 & \\
\hline Juniperus communis & & & & & & 1 & & & & & & & & & \\
\hline Pinus sylvestris & & & & & & & 2 & & & 1 & & & & & \\
\hline Betula sp. & & 3 & & & & & & & 2 & & & & 1 & & \\
\hline \multicolumn{16}{|l|}{ Populus sp. } \\
\hline Quercus sp. & & & 2 & 3 & 11 & & 1 & 1 & & & 1 & 1 & & & \\
\hline Broad-leaved & & & & & & & & & & & & & & & 1 \\
\hline Conifer & & & & & & & 1 & & & & & & & & \\
\hline Sum of fragments & 1 & 4 & 2 & 3 & 12 & 1 & 4 & 1 & 3 & 1 & 1 & 1 & 1 & 1 & 1 \\
\hline Minimum Number of Taxa & 1 & 2 & 1 & 1 & 2 & 1 & 2 & 1 & 2 & 1 & 1 & 1 & 1 & 1 & 1 \\
\hline \multicolumn{16}{|l|}{ Indeterminable } \\
\hline Branch & & & & & & 1 & & & & & & & & & \\
\hline \multicolumn{16}{|l|}{ Trunk } \\
\hline $\begin{array}{l}\text { Fungi and insects (number } \\
\text { of charcoal fragments) }\end{array}$ & & 2 & & & & & & & & & & & & & \\
\hline
\end{tabular}

Eastern Roztocze (Kobyle Jezioro: KonzeŃ et al. 2015) which allows to date PinusFagus-Sphagnum zone in profile 118 and the upper section of Pinus-Cerealia-Plantago lanceolata zone in profile 71 to that period. The occurrence of Fagopyrum pollen in both profiles suggests that the upper sections of these diagrams represent the Middle Ages. If so, the information about the vegetation during the time of the existence of Wielbark culture settlement is recorded in profile 71 only in the two pollen spectra from 65 and $60 \mathrm{~cm}$ depth and in profile 118 in the whole Pinus-Fagus-Sphagnum zone. Pollen spectra from both profiles suggest the appearance of fir in this area, the increased significance of beech and pine and in profile 118 the decreased role of hornbeam and lime. According to the potential natural vegetation map for this area (Fig. 9) (MATUSZKIEWICZ 2008) a considerable area in the surroundings of Ulów could have been overgrown by woods formed by beech, fir and some spruce with hazel in the shrub layer. They could resemble the east-Carpathian form of the Carpathian beech-forest (Dentario glandulosae-Fagetum). Also oak-hornbeam-lime forests (TilioCarpinetum) could have grown in the vicinity. Slightly more distant were probably habitats suitable for the mixed oak-pine (Querco-Pinetum), pine (Leucobryo-Pinetum) and fir (Abietetum polonicum) forests (MATUSZKIEWICZ 2008).

Among charcoals present in the burials and at the settlements, 13 different taxa were documented. In the cemetery, hornbeam and beech charcoals occurred in small numbers while in the settlement beech was the second tree species with respect of the number and ubiquity of fragments and confirm the occurrence of beech forest near 
Table 8. Continued

\begin{tabular}{|c|c|c|c|c|c|c|c|c|c|c|c|c|c|c|c|c|c|c|c|c|}
\hline \multicolumn{3}{|c|}{58} & \multicolumn{4}{|c|}{59} & \multicolumn{9}{|c|}{62} & \multicolumn{3}{|c|}{65} & \multirow{2}{*}{$\begin{array}{l}\text { Sum of } \\
\text { frag- } \\
\text { ments }\end{array}$} & \multirow{2}{*}{$\%$} \\
\hline P3 & P10 & P6 & P9 & P15 & P7 & P8 & 807 & 816 & 801 & 817 & 810 & 800 & P1W & P2 & P1E & 822 & 823 & 825 & & \\
\hline & & & & & & & & 1 & & & & & & & & & & & 1 & 0.3 \\
\hline & & & & 4 & 1 & & & 1 & & & & & & & & 2 & & 1 & 12 & 4.2 \\
\hline \multirow[t]{9}{*}{16} & 20 & 18 & & & & & & & & & & & & & & & & & 55 & 19.1 \\
\hline & & & & & 2 & 1 & & & & & & & & & & & & & 4 & 1.4 \\
\hline & & & & & & & & & & & & & & & & & & & 1 & 0.3 \\
\hline & & & & 2 & 2 & 2 & & & & & & & & & & & 1 & & 10 & 3.5 \\
\hline & & & & & 1 & 2 & & & & & & & & & & & & & 9 & 3.1 \\
\hline & & & & & & & & & & & & & & & & & 1 & & 1 & 0.3 \\
\hline & & & 10 & 12 & 6 & 9 & 16 & 12 & 30 & 2 & 2 & 30 & 20 & 18 & 2 & & & & 189 & 65.6 \\
\hline & & 1 & & 2 & & & & & & & & & & & & & & & 4 & 1.4 \\
\hline & & 1 & & & & & & & & & & & & & & & & & 2 & 0.7 \\
\hline 16 & 20 & 20 & 10 & 20 & 12 & 14 & 16 & 14 & 30 & 2 & 2 & 30 & 20 & 18 & 2 & 2 & 2 & 1 & 288 & 100 \\
\hline \multirow[t]{5}{*}{1} & 1 & 2 & 1 & 3 & 5 & 4 & 1 & 3 & 1 & 1 & 1 & 1 & 1 & 1 & 1 & 1 & 2 & 1 & & \\
\hline & & & & & & & & & & & & & & & & & & & & \\
\hline & & 2 & & & & & & & & & & & 12 & 8 & & & & & & \\
\hline & & & & & & & 16 & & 30 & 2 & 2 & 30 & 8 & 10 & & & 1 & 1 & & \\
\hline & & & & & 1 & & & & & & & & & & & & 1 & 1 & & \\
\hline
\end{tabular}

the site. Fir occurred both in the settlement and the cemetery of the Wielbark culture but its remnants were very scarce. The remains of birch were the most frequent in the cemetery, followed by pine and alder, while oak was the most frequent at the settlement. The graves usually did not comprise a large amount of charcoals, and it is clear that only part of the cremation pyres were transported from ustrinum and finally deposited in the burials. Also, in many graves, bones were deposited in an organic container and were evidently previously cleaned from the remnants of the pyre, leaving only sporadic and tiny charcoals. The remains of wood could also represent remnants of other fuel wood used during funeral ceremonies. Nevertheless, based on the taxonomic diversity of the charcoal assemblage coming from graves, it can be concluded that wood of different species was used for incineration. In addition, wood of different calibre was utilized as trunks and branches were documented. Part of fuels could have been achieved from deadwood.

A high frequency of birch and pine was documented in other cremation cemeteries from the Late Bronze Age and the Roman Period (e.g. Moskal-Del Hoyo 2012; LiTYŃSKA-ZAJĄC et al. 2014). Birch wood could have been selected due to the ignition properties of its bark, which contains a chemical compound called betulin that is responsible for rapid ignition of even fresh and wet wood. This substance also allows birch wood to reach higher temperatures during burning (LITYŃSKA-ZAJĄC et al. 2014). Pine wood might have been especially chosen due to its aromatic properties since the resinous wood is known for the pleasant fragrance it releases while burning. Birch and 


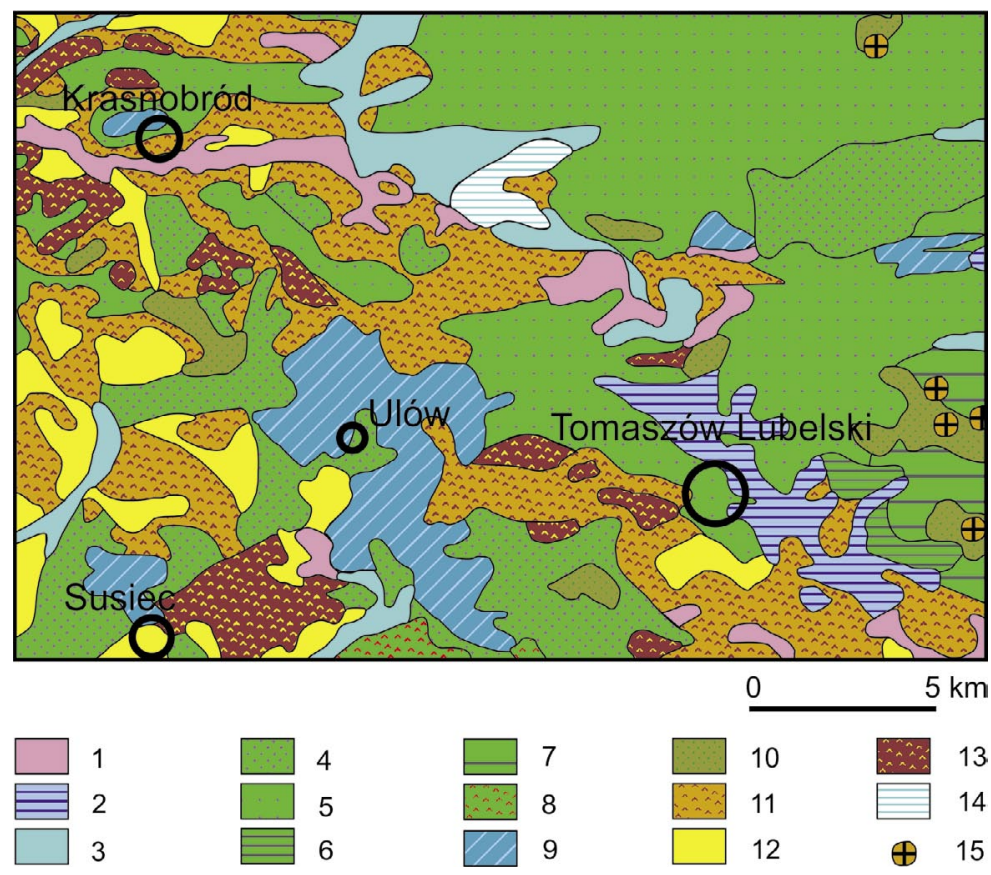

Fig. 9. The potential natural vegetation in the surroundings of Ulów. 1 - Carici elongatae-Alnetum, 2 - Ficario-Ulmetum, 3 - Fraxino-Alnetum, 4 - Tilio-Carpinetum, Little Poland, poor series, 5 - TilioCarpinetum, Little Poland, rich series, 6 - Tilio-Carpinetum, Little Poland, Volhynian poor series, 7 Tilio-Carpinetum, Little Poland, Volhynian rich series, 8 - Tilio-Carpinetum with Abies, 9 - Dentario glandulosae-Fagetum, 10 - Potentillo albae-Quercetum, 11 - Querco-Pinetum, 12 - Leucobryo-Pinetum, 13 - Abietetum polonicum, 14 - waters, 15 - Festucetalia valesiacae. From J.M. Matuszkiewicz 2008

pine were also found in a few cemeteries of the Wielbark culture from north-eastern Poland. These trees dominated the charcoal assemblages from Jasionowa Dolina, but hornbeam and spruce were also identified (SŁAWIŃSKI et al. 1958; CZECZUGA, KŁYSZEJKo 1974). In the necropolis of Cecele, 11 taxa appeared, but birch and oak were the most widespread, while pine was sporadically found (CzECZUGA, KŁYSZEJKo 1972).

The oldest traces of agricultural activity in the Roztocze appear in the Atlantic period. In Tarnawatka and Krasnobród pollen diagrams (BALAGA 1989) they include plant indicators of animal husbandry and forest clearings and a few ruderal plants but the first scattered cereal pollen grains appear as late as the mid-Subboreal. In Tarnawatka cereals are absent in most part of the Subatlantic while in the Krasnobród profile they form low but almost continuous curves. In Hamernia (MARGIELEWSKI et al. 2015) the first cereals appear in the Subatlantic.

In both profiles from Ulów human indicator plants appear in the Subboreal period. They are more abundant in profile 71 , where wheat, rye and undetermined cereal pollen occur together with a few meadow and pasture plants indicating that some agricultural activity was taking place in the neighbourhood. Profile 118 contains only a few cereal pollen grains from that time. Plant macrofossils dated to the Subboreal period 
are hitherto only very scanty from the Ulów region. In a probably Neolithic feature no. 26 at site 3 the imprints of barley and millet caryopses were found together with grass leaves and culms and one charred Melandrium sp. seed. At the same site wood charcoal of ash from a grave of the Corded Ware culture was radiocarbon dated to $4045 \pm 35$ BP (Moskal-Del Hoyo et al. 2017).

In the Subatlantic section of pollen diagram 118 cereal pollen is absent while the two samples which may represent Subatlantic in profile 71 contain rye and wheat pollen type and a few indicators of grazing. A small number of Pteridium aquilinum spores recorded in both pollen profiles may indicate that forest clearings were taking place in the area. More complete information about agricultural activity of the Wielbark culture population can be deduced from the list of plants recovered from daub combined with the Subatlantic pollen spectra.

The main cereals were barley (Hordeum vulgare) and millet (Panicum miliaceum) but emmer and/or einkorn wheat (Triticum dicoccon or T. monococcum) were also cultivated. Quantitative dominance of millet and barley (Fig. 10) suggests their important economic role which agrees with the other data coming from the Roman Period in the whole Poland (LiTYŃSKa-ZAJĄC, WaSYLIKOwa 2005: 495). The problem of rye cultivation is somewhat enigmatic. Several other sites of various cultures from the Roman Period in Poland provide evidence of rye cultivation (LiTYŃSKA-ZAJĄC 1997). In Ulów rye was not found in any archaeologically well dated feature. One charred caryopsis was recovered only from feature 71 , site 3 , which contained some artefacts from the Roman Period but could not be dated precisely (NIEZABITOWSKA-WiśNIEWSKA, personal com.). In the profile 118 and also in the diagrams from Tarnawatka and Krasnobród rye pollen curves appear as late as early Middle Ages. Also in the diagram from Kobyle Jezioro in the Eastern Roztocze (KoRzeń et al. 2015) rye does not appear before the Middle Ages. The continuous rye pollen curve begins also late (about the $8^{\text {th }}$ century) in pollen diagrams from Pagóry Chełmskie, a region north of the Roztocze (DoBROwOLSKI et al. 2015). Could this mean that rye was not cultivated in this part of Poland in the Roman
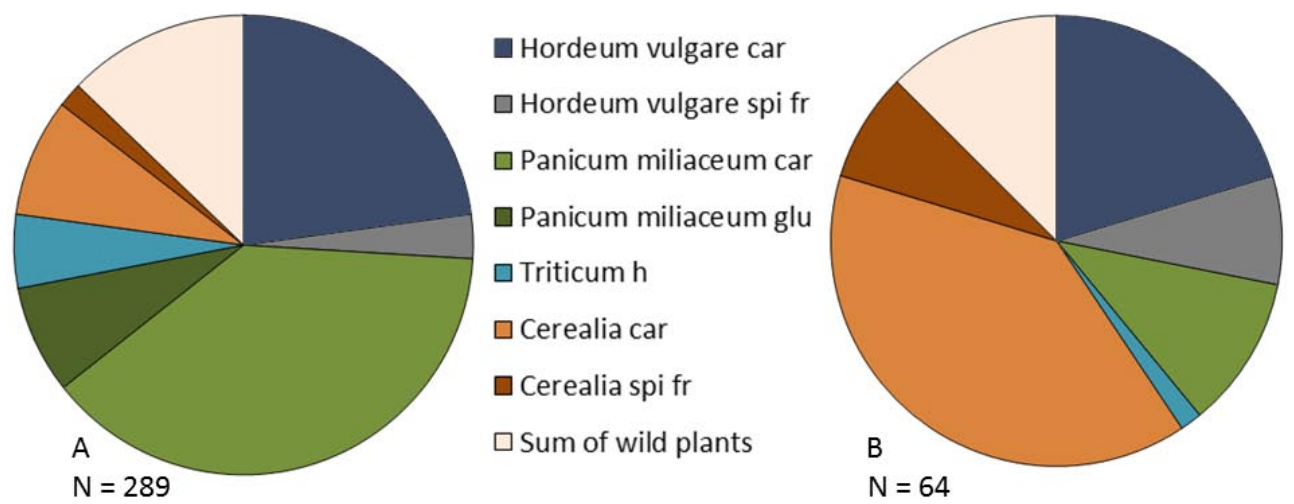

Fig. 10. Percentage proportions of diaspores of cereals and wild herbaceous plants at site 9: A - in all features, B - in all samples from the layer. Explanations: car - caryopsis, spi fr - spike fragments, $\mathrm{h}$ - hulled, glu - glumed 
Table 9. Habitats represented by herbs found in pollen diagrams and among macrofossils recovered from daub pieces. Explanations: ma - fruits/seeds, mi - pollen

\begin{tabular}{|c|c|c|c|c|c|c|c|c|}
\hline Plant taxa & $\begin{array}{l}\text { Kind of } \\
\text { remain }\end{array}$ & Fields & $\begin{array}{c}\text { Ruderal } \\
\text { sites }\end{array}$ & Meadows & Pastures & $\begin{array}{l}\text { Water } \\
\text { shores }\end{array}$ & $\begin{array}{c}\text { Xerothermic } \\
\text { grasslands }\end{array}$ & Forests \\
\hline Chenopodium album & ma & $* * * * *$ & & & & & & \\
\hline $\begin{array}{l}\text { Chenopodium } \mathrm{cf} \\
\text { polyspermum }\end{array}$ & ma & $* * * * *$ & & & & & & \\
\hline Echinochloa crus-galli & $\mathrm{ma}$ & $* * * * *$ & & & & & & \\
\hline Lapsana communis & $\mathrm{ma}$ & $* * * * *$ & & & & & & \\
\hline Galium spurium & $\mathrm{ma}$ & $* * * * *$ & & & & & & \\
\hline Setaria pumila & $\mathrm{ma}$ & $* * * * *$ & & & & & & \\
\hline Rumex acetosella & $\mathrm{ma}$ & $* * * * *$ & & & & & & \\
\hline Solanum nigrum & $\mathrm{ma}$ & $* * * * *$ & & & & & & \\
\hline Fallopia convolvulus & $\mathrm{ma}$ & $* * * * *$ & $* * * * *$ & & & & & \\
\hline Polygonum aviculare & ma mi & $* * * * *$ & $* * * * *$ & & $* * * * *$ & & & \\
\hline Setaria viridis/verticillata & ma & $* * * * *$ & $* * * * *$ & & & & & \\
\hline Melandrium album & $\mathrm{ma}$ & $* * * * *$ & $* * * * *$ & & & & & \\
\hline Polygonum persicara t. & $\mathrm{mi}$ & $* * * * *$ & & & & $* * * * *$ & & \\
\hline Sambucus cf. ebulus & $\mathrm{mi}$ & & $* * * * *$ & & & $* * * * *$ & & \\
\hline Artemisia & $\mathrm{mi}$ & & $* * * * *$ & & & & $* * * * *$ & \\
\hline Urtica & $\mathrm{mi}$ & & $* * * * *$ & & & & & $* * * * *$ \\
\hline Prunella vulgaris & $\mathrm{ma}$ & & $* * * * *$ & $* * * * *$ & & & & \\
\hline Rumex acetosa t. & $\mathrm{mi}$ & & & $* * * * *$ & & & & \\
\hline Plantago lanceolata & $\mathrm{mi}$ & & & $* * * * *$ & & & & \\
\hline Ranunculus acris $\mathrm{t}$. & $\mathrm{mi}$ & & & $* * * * *$ & & & & \\
\hline Filipendula (if ulmaria) & $\mathrm{mi}$ & & & $* * * * *$ & & & $* * * * *$ & $* * * * *$ \\
\hline Centaurea scabiosa $\mathrm{t}$ & $\mathrm{mi}$ & & & & & & $* * * * *$ & \\
\hline cf. Lolium perenne & $\mathrm{ma}$ & & & & $* * * * *$ & & & \\
\hline Plantago maior/media & $\mathrm{mi}$ & & & $* * * * *$ & $* * * * *$ & & $* * * * *$ & \\
\hline cf. Carum carvi & $\mathrm{ma}$ & & & $* * * * *$ & $* * * * *$ & & & \\
\hline Humulus/Cannabis & $\mathrm{mi}$ & & & & & & & $* * * * *$ \\
\hline Melandrium rubrum & $\mathrm{ma}$ & & & & & & & $* * * * *$ \\
\hline Lythrum (if salicaria) & $\mathrm{mi}$ & & & $* * * * *$ & & & & $* * * * *$ \\
\hline Comarum palustre & $\mathrm{mi}$ & & & & & $* * * * *$ & & \\
\hline Typha latifolia & $\mathrm{mi}$ & & & & & $* * * * *$ & & \\
\hline Pteridium aquilinum & $\mathrm{mi}$ & & & & & & & $* * * * *$ \\
\hline
\end{tabular}

Period, that it grew in fields only as a weed? The elucidation of this question requires more archaeobotanical studies from the Roztocze region.

Among 30 species of herbaceous plants there are 13 weeds nowadays growing mainly in the root-crop cultivations, in millet fields and in gardens (Tab. 9) (MATUsZKIEWICZ 2001; ZARZYCKI et al. 2002). The decisive agent of their growth is not a species of cultivated plant but the way of soil tillage consisted in weeding several times during one season. In our material Chenopodium album and Ch. cf. polyspermum, Echinochloa crus-galli, Lapsana communis, Setaria pumila, S. viridis or S. verticillata, Solanum nigrum, Galium spurium and Polygonum persicaria belong to this category. 
Three species Melandrium album, Rumex acetosella and Fallopia convolvulus can grow among the root crops as well as in cereal fields. All these species were often found in the deposits of charred cereal grain on the other archaeological sites in Poland (LiTYŃSKA-ZAJĄC 2005). At Ulów there is no evidence of the typical root crops cultivation therefore these weeds grew probably in millet fields or perhaps barley and wheat fields were also weeded. Some species of Cerastium sp. and Stellaria sp. could also belong to weeds. In pollen diagrams the occurrence of weeds is indicated by the curves of Chenopodiaceae, Galium sp., Poaceae and Caryophyllaceae.

Meadows and pastures are better represented in pollen diagram than among the macro-remains (Tab. 9). Several species could originate from such communities: Polygonum aviculare, represented by one fruit and the pollen curve; cf. Lolium perenne and Prunella vulgaris represented by fruits; cf. Carum carvi preserved as one fruit and perhaps included in pollen curve of Apiaceae; Plantago lanceolata, P. maior, $R a-$ nunculus acris t. and Comarum palustre recorded only in pollen spectra. Melandrium rubrum represented by one seed could accidentally get in fields from alder carrs. A few species occurred probably on rich in nitrogen ruderal places close to the settlement, e.g. Sambucus ebulus, Artemisia, Urtica, all represented only by pollen grains. A few other species of herbs could originate from water shore communities (only pollen), some from xerothermic habitats (only pollen) and from forests (mostly pollen). The difference in the set of anthropogenic indicators between pollen spectra and the content of daub probably resulted from the fact that weeds were only accidentally mixed with barley and millet straw added to clay.

ACKNOWLEDGEMENTS. The authors want to express their thanks to Dr. Barbara Niezabitowska-Wiśniewska for inviting to cooperation, for making possible to collect profiles for pollen analysis, providing material for carpological and anthracological studies and making available all necessary information about the site. The first author thanks Dr. hab. Jan Rodzik and Dr. Przemysław Mroczek for the help in coring. The second author thanks Prof. Dr. hab. Halina Bednarek-Ochyra for checking the recognition of Bryophytes remnants. The authors are grateful to all referees for their valuable comments. The research was financed by the National Science Centre in Poland (project number DEC-2013/09/B/HS3/03352). Part of the work was supported by the Statutory Research Tasks of the W. Szafer Institute of Botany of the Polish Academy of Sciences.

\section{SUMMARY}

The studies of plant material from Ulów contributed to the broadening of our knowledge of the natural environment in which the Wielbark culture population settled down and carried out its agricultural activity in Poland. Pollen analysis of 4 discontinuous profiles collected near the settlement complex at Ulów allowed the reconstruction of fragmentary vegetation episodes dated to the Subboreal and late Subatlantic (Middle Ages). In the Subboreal period the area was covered by forests with oak, hornbeam, lime, beech, and spruce on moister soils. Wet habitats were occupied by alder woods with ash and elm. Single cereal pollen grains and pollen curves of herbs indicating animal grazing suggest that some human activities took place in the area but archaeological evidence of the local presence of people is limited to one grave of the Corded Ware culture. In the Subatlantic forest transformations took place due to the appearance of fir. The settlement of the Wielbark culture developed in this area during the late Roman and the early phase of the Migration periods. Pollen curves of herbaceous plants together with plant 
impressions recovered from the daub provided information about plant cultivation and animal grazing. Barley Hordeum vulgare and millet Panicum miliaceum were the main cereals, a species of hulled wheat emmer Triticum dicoccon or einkorn T. monococcum was also cultivated. Most of the wild plants represented by seeds/fruits belonged to root crop weeds (e.g. Chenopodium album, Ch. cf. polyspermum, Setaria pumila, S. viridis or $S$. verticillata, Echinochloa crus-galli, Galium spurium), some could grow among root crops and in cereal fields (Melandrium album, Polygonum aviculare, Fallopia convolvulus). The representation of weeds was less clear in pollen diagrams, probably these were the curves of Chenopodiaceae, Galium sp., Poaceae and Caryophyllaceae. On the other hand meadows and pastures were poorly represented among macrofossils but better in pollen diagrams. This difference could have been caused by the fact that field weeds were mixed with straw added to clay.

The results of wood charcoal analysis indicated the diverse exploitation of timber both as fuel used in everyday activities and for the construction of pyres. In the vicinity of the settlement wood of oak and beech was most often gathered while for making funerary pyres birch and pine wood was mainly used. Charcoals recovered from archaeological sites are an important source of information about the local forest stands. In the case of the Wielbark culture sites the local occurrences of hornbeam, beech and fir were confirmed.

\section{REFERENCES}

Bataga K., 1998. Post-glacial vegetational changes in the Middle Roztocze (E Poland). Acta Palaeobotanica 38(1): 175-192.

BeHRE K-E., 1981. The interpretation of anthropogenic indicators in pollen diagrams. Pollen and Spores 23: $225-245$.

Berglund B., Ralska-Jasiewiczowa M., 1986. Pollen analysis and pollen diagrams. In: Berglund B.E. (Ed.) Handbook of Holocene Palaeoecology and palaeohydrology. John Willey \& Sons, Chichester: 455-484.

Chabal L., 1997. Forêts et sociétés en Languedos (Néolithic final, Antiquité tardive). L'athracologie, méthode et paléoécologie. Documents d'Archéologie Française 63, Éditions de la Maison des sciences de l'homme, Paris.

Czeczuga B., KŁyszejko E., 1972. Węgle drzewne z kurhanów w miejscowości Jasionowa Dolina, pow. sokólski. Rocznik Białostocki 11: 344-347.

Czeczuga B., KŁyszejko E., 1974. Węgle z grobów z okresu rzymskiego kultury-wschodnio-pomorskomazowieckiej w Cecelach, pow. siematycki. Rocznik Białostocki 12: 335-337.

Dobrowolski R., Dzieńkowski T., Pidek I.A., Michczyńska D.J., Łojek J., Kulesza P., 2015. Naturalne i antropogeniczne zmiany warunków środowiska we wczesnym średniowieczu w rejonie Chełma w zapisie osadów biogenicznych stanowiska Bezedna. Prace i Materiały Muzeum Archeologicznego i Etnograficznego w Łodzi, seria Archeologiczna 46(2013-2015): 37-54.

IzDEBSKI K., 2002. Szata roślinna i jej ochrona. In: BuRACZYŃsKi J. (Ed.), Roztocze - środowisko przyrodnicze. Wyd. Lubelskie, Lublin: 272-321.

Izdebski K., Czarnecka B., Grądziel T., Lorens B., Popiolek Z., 1992. Zbiorowiska roślinne Roztoczańskiego Parku Narodowego na tle warunków siedliskowych. Wyd. UMCS, Lublin.

JANCZYK-KoPIKOWA Z., 1987. Uwagi na temat palinostratygrafii czwartorzędu. Geological Quarterly 31: $155-163$.

Korzeń K., Margielewski W., Nalepka D., 2015. Neoholocene palaeoenvironmental changes in the Southern Roztocze region (SE Poland): The Kobyle Jezioro raised bog case study. Quaternary International 389: 191-202. 
Latalowa M., 2003. Holocen (Holocene). In: Dybova-Jachowicz S., Sadowska A. (Eds.), Palinologia. W. Szafer Institute of Botany, Polish Academy of Sciences, Kraków: 273-292.

LiTYŃSKA-ZAJĄC M., 1997. Roślinność i gospodarka rolna w okresie rzymskim. Instytut Archeologii i Etnologii PAN, Kraków

LiTYŃSKA-ZAJąC M., 2005. Chwasty w uprawach roślinnych w pradziejach i wczesnym średniowieczu. (Segetal weeds in Prehistoric and early Medieval Farming, in Polish with English summary). Instytut Archeologii i Etnologii PAN/Institute of Archaeology and Ethnology, Polish Academy of Sciences, Kraków.

Lityńska-Zając M., Wasylikowa K., Cywa K., Tomczyńska Z., Madeyska E., Koziarska A., SkawińsKaWieSER K., 2014. Brzezie, stan. 17, gm. Kłaj. Materiały archeobotaniczne z obiektów kultury ceramiki wstęgowej rytej. In: Czekaj-Zastawny A. (Ed.), Brzezie 17. Osada kultury ceramiki wstęgowej rytej. Via Archaeologica, Źródła z badań wykopaliskowych na trasie autostrady A4 w Małopolsce. Krakowski Zespół do Badań Autostrad, Kraków, 405-436.

LityŃSKa-ZająC M., WasYlikowa K., 2005. Przewodnik do badań archeobotanicznych. In: FalińsKi J.B. (Ed.) Vademecum Geobotanicum. Sorus, Poznań.

Makohonienko M., 2000. Przyrodnicza historia Gniezna. Homini, Bydgoszcz-Poznań.

Margielewski W., Krąiec M., Jankowski L., Zernitskaya V., 2015. Impact of aeolian processes on peat accumulation: Late Glacial-Holocene history of the Hamernia peat bog (Roztocze region, southeastern Poland). Quaternary International 386: 212-225.

Marguerie D., HunOt J.-Y., 2007. Charcoal analysis and dendrology: data from archaeological sites in north-western France. Journal of Archaeological Science 34: 1417-1433.

Matuszkiewicz J. M., 2008. Potential natural vegetation of Poland, map sheet: C4. IGiPZ PAN, Warszawa.

Matuszkiewicz W., 2001. Przewodnik do oznaczania zbiorowisk roślinnych Polski. In: Falı́́ski J.B., (Ed.) Vademecum Geobotanicum, Wydawnictwo Naukowe PWN, Warszawa.

Moskal-Del Hoyo M., 2012. The use of wood in funerary pyres: random gathering or special selection of species? Case study of three necropolises from Poland. Journal of Archaeological Science 39(11): $3386-3395$.

Moskal-del Hoyo M., Krąpiec M., Niezabitowska-Wiśniewska B., 2017. The Chronology Of Site 3 In Ulów (Tomaszów Lubelski District, East Poland): The Relevance of Anthracological Analysis for Radiocarbon Dating at a Multicultural Site. Radiocarbon 59(5): 1399-1413.

Moskal-del Hoyo M., Wachowiak M., Blanchette R.A., 2010. Preservation of fungi in charcoal. Journal of Archaeological Science 37(9): 2106-2116.

Nalepka D., Walanus A., 2003. Data processing in pollen analysis. Acta Palaeobotanica 43(1): 125-134.

NieZABITOWSKA-WiśNiEwsKa B., 2008. Kompleks osadniczy w Ulowie, powiat tomaszowski - wstępne podsumowanie sześcioletnich badań wykopaliskowych. Archeologia Polski Środkowowschodniej X: 67-93. In Polish with English summary.

NieZABITOWSKA-WiŚNIEWSKA B., 2017. Archaeological research results of the settlement micro-region in the area of Ulów in Middle Roztocze in the light of the project "Roztocze - the ancient terra incognita?...”. Folia Quaternaria 85: 5-47.

NiEZABITOWSKA-WiśNIEWSKA B., WIŚNIEWSKI T., 2011. Kurhany kultury ceramiki sznurowej na stanowisku 3 w Ulowie, powiat tomaszowski. Str. 329-369. In: KowalewsKa-MarszaleK H., WlodarcZaK P. (Eds.) Kurhany i obrządek pogrzebowy w IV-II tysiącleciu p.n.e. Instytut Archeologii i Etnologii Polskiej Akademii Nauk, Instytut Archeologii Uniwersytetu Warszawskiego, Kraków, Warszawa

RalSKa-Jasiewiczowa M., 2006. Some comments on the palynostratigraphy of the Holocene in Poland, based on isopollen maps. Studia Quaternaria 23: 29-35. 
Ralska-Jasiewiczowa M., Miotk-Szpiganowicz G., Zachowicz J., Latalowa M., Nalepka D., 2004. Carpinus betulus L. - Hornbeam. In: Ralska-Jasiewiczowa M., Latalowa M., Wasylikowa K., Tobolski K., Madeyska E., Wright H.E., JR., Turner Ch. (Eds.), Late Glacial and Holocene History of Vegetation in Poland based on isopollen Maps. W. Szafer Institute of Botany, Polish Academy of Sciences, Kraków, p. 69-78.

Rodzik J., Nitychoruk J., 2017. Abiotic environmental conditions of former settlement in the vicinity of Ulów in Roztocze (SE Poland). Folia Quaternaria 85: 65-79.

Schweingruber F. H., 1990. Anatomie Europäischer Hölzer. Paul Haupt Berne und Stuttgart Publishers, Bern-Stuttgart.

SŁawiŃski W., Gierasimow M., KościK A., 1958. Szczątki roślinne z kurhanów z okresu rzymskiego odkryte na Suwalszczyźnie. Wiadomości Archeologiczne 25: 145-148.

Thèry-PARISOt I., 2001. Économie du combustible au Paléolithique. Anthracologie, Expérimentation, Taphonomie. Dossier de Documentation Archéologique, 20, C.N.R.S., Paris.

West R.G., 1970. Pollen zones in the Pleistocene of Great Britain and their correlation. New Phytologist 69: 1179-1183.

Zarzycki K., Trzcińska-Tacik H., Różański W., Szeląg Z., Wolek J., KorZeniak U., 2002. Ecological indicator values of vascular plants of Poland. W. Szafer Institute of Botany, Polish Academy of Sciences, Kraków. 